\title{
THE GOLDEN AGE OF NOBEL ECONOMISTS
}

\author{
Hendrik P. van Dalen
}

Research Center for Economic Policy (OCFEB) and Tinbergen Institute, Erasmus University Rotterdam, P.O. Box 1738, 3000 DR Rotterdam; Netherlands Interdisciplinary Demographic Institute (NIDI), P. O. Box 11650, 2502 A R The Hague, The Netherlands; email: dalen@nidi.nl

November 3, 1997

Keywords: A ge, Economists, N obel Prize, Productivity

JEL classification: A 11, J24, J 44

A bstract:

Nobel laureates in economics make their most important and creative contributions between the ages of 29 and 38. The average creative age of Nobel economists is slightly below that of laureates in physics, and considerably younger than that of laureates in chemistry and medicine/physiology. The U niversity of Chicago and the US in general has so far turned out to be best breeding ground for original economists. Furthermore, most fundamental work has been written alone and this finding contrasts strongly with the dominant trend in economics where multi-authored papers have become the rule in publishing. 


\section{Introduction}

Science is a creative and human affair and economic science is no exception to this rule. Discovering how knowledge comes about and is destroyed is not only an interesting pastime for rainy sunday afternoon, it goes right to the heart of discussions on, e.g. endogenous growth, the economic consequences of aging populations, personnel economics, patent races and the philosophy of science. ${ }^{1}$ We will not make the mistake of dealing with each and every of these grand issues, but stick to dealing with only one issue, viz. whether age and productivity are related and if so, how important this is. Empirical studies of productivity suggest that even star economists do not escape from the inverted U-shape of lifetime productivity as measured by citations and publications. ${ }^{2}$ The tracking down of individual productivity is a difficult question to solve for a number of reasons: lifetime productivity data are only available on a limited basis and the quality of ideas is to some extent a subjective affair. Furthermore, the scientific reward system is of a winner-takes-all nature, hence the praise for ideas and its discoverers is unevenly distributed across the community of scientists. The distribution of attention is highly skewed towards the happy few who either have the gift of the gab or who know how to make an idea 'sing'. ${ }^{3}$ Productivity studies are going to be misleading if one does not take account of these idiosyncracies of academia. One way to solve the aforementioned problem is to focus on the superstars of economics who have survived the rat race and track the individual productivity over their lifetime. To some extent they have received the same 'unfair' treatment which the starlets in science so desparately seek. Nobel laureates in economics seem excellent candidates to examine in some detail, for one thing because these eminent scientists belong to a very small elite who dominate the market for basic knowledge.

We start with reviewing some of the old precursors who have examined the question of age-related productivity in some detail and then we go on to see how important age is for scientific productivity among Nobel laureates in economics and what other factors might influence the productivity of economists.

\section{Beard's L aw Revisited}

The recognition of age as a prime determinant of achievement has firm roots in the history of science. The first to put forward an idea about the relationship between age and productivity was George Miller Beard, a N ew York physician who collected material from the biographies of "nearly all the greatest names in history"

1. Other and similar reasons were mentioned by Colander (1989) and recently by Backhouse et al. (1997).

2. See Oster and Hamermesh (1997), Goodwin and Sauer (1995) and Kenny and Studley (1995).

3. Cox and Chung (1991) show that the concentration of authors conforms well to Lotka's Law of scientific productivity: the number of authors publishing $n$ papers is about $1 / n^{c}$ of those publishing one paper, where the exponent c turns out to be 1.84 for a large collection of journals (Lotka proposed the same law in 1926 but a priori assumed that $\mathrm{c}$ is 2 ). 
(1874). He computed the mean age at which these men and women accomplished their most original work, followed their output over time, and derived so a law of the relation between age and original work. Figure 1 reproduces his vision on the productivity-age relationship, with age on one axis and creative output on the other.

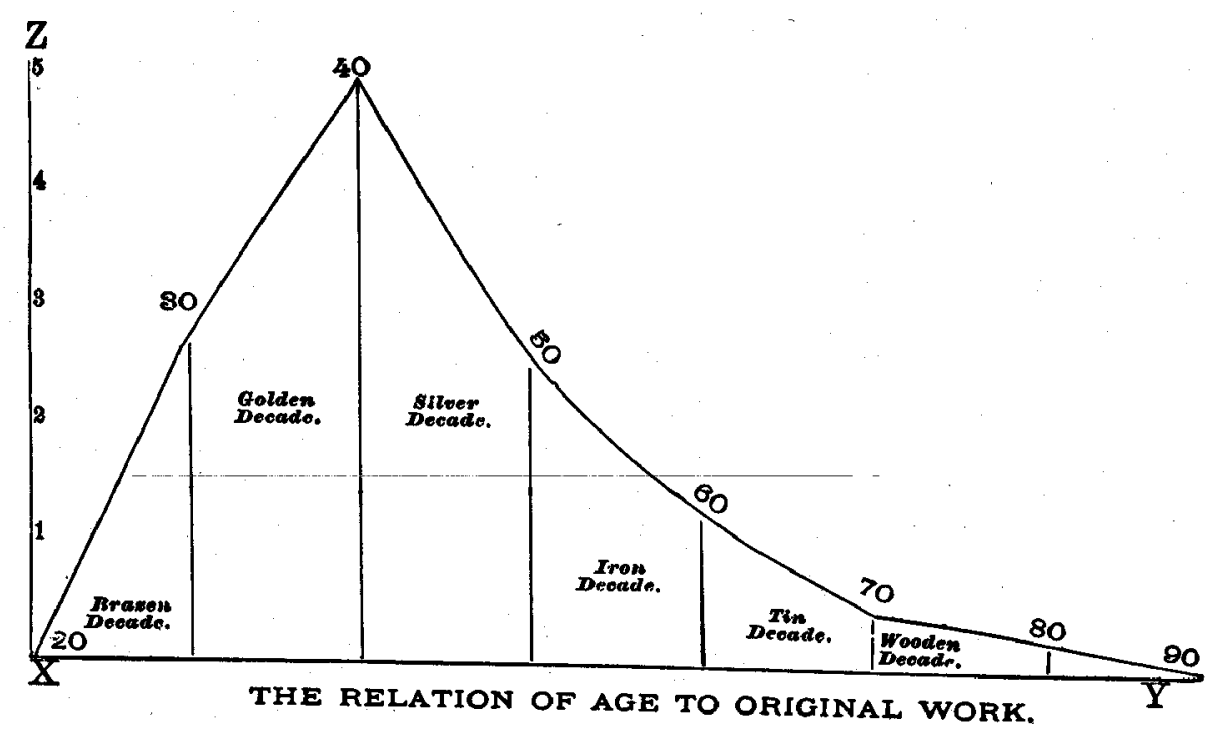

Based on his bibliometric efforts he states that "seventy percent of the work of the world is done before fortyfive, and eighty percent before fifty." (Beard, 1881) The productivity curve simply mirrors in his view the process of growth, maturity, and decay of human organism as a whole: the "nervous, muscular, and osseous systems rise, remain and fall together." (p. 249) In his clinical manner he labelled the six decades between twenty and eighty according to their level of productivity: 'brazen', 'golden', 'silver', 'iron', 'tin' and the 'wooden' decade. With equal clinical zest he applied his scheme to worldly affairs when he argued that it was a "barbarian folly" to believe that men were capable of governing others only when "their own brains have begun to degenerate, and the fires of youth have spent half their force." According to his humble opinion he thought that the aging of the work force could explain the "enormous stupidity and backwardness and redtapeism of all departments of government everywhere."

Despite his methodologically sloppy research and his simplistic views on ageing, Beard was the first to investigate the age-productivity relationship. Some would, of course, mark it as a dubious distinction because Beard's law is the first scientific legitimation of reducing human beings to their productive capacities. Such a translation was something quite unheard of at that time. It would take more than sixty years before the psychologist Lehman (1953) took up the challenge to perform a similar exercise. His massive Beardian exercise covered 170 figures with age-productivity profiles which generally showed that the output among 
creative scientists for their best work reached a peak during their thirties and then gradually declined. Cole (1979) later went on to note that it matters to take account of the selection process inside academia. The publication productivity of mathematicians remained fairly constant over their lifetime if they keep up the rat race in publishing. The 'perishable' scientists, however, may give rise to the inverted $U$-shape which one comes across in so many cross-section productivity studies.

The efforts of science watchers to get a grip on the element of productivity are usually clouded by the uncertainty surrounding the concepts of 'product' and 'production' in science. M easuring productivity is going to be a haphazard affair, if it is not restricted to some definition of quality. Nobel laureates differ with respect to achievement measures and defining productivity along the lines of only one measure will put into question why some $\mathrm{N}$ obel laureates received their prize in the first place. The most common measures are citations as measured by the Social Science Citation Index (SSCI) and the number of articles and books published. The ages registered in Table 1 enable us to discern at what age one started publishing creative ideas for which one later in life received the Nobel Prize, and at what age one started an academic (publishing) career.

Table 1: Nobel prize laureates in economics, 1969-1997

\begin{tabular}{|c|c|c|c|c|c|c|c|}
\hline \multirow[b]{2}{*}{$\begin{array}{l}\text { Nobel } \\
\text { year }\end{array}$} & \multirow[b]{2}{*}{ Nobel laureate } & \multicolumn{6}{|c|}{ A ge at which one received c.q. published: } \\
\hline & & $\begin{array}{l}\text { Nobel } \\
\text { Prize } \\
\end{array}$ & $\begin{array}{c}\text { First } \\
\text { publication }\end{array}$ & $\mathrm{PhD}$ & $\begin{array}{l}\text { Breakthrough } \\
\text { publication }\end{array}$ & $\begin{array}{l}\text { Start N obel } \\
\text { Prize work }\end{array}$ & $\begin{array}{c}\text { M other lode } \\
\text { publication }\end{array}$ \\
\hline \multirow[t]{2}{*}{1969} & J. Tinbergen (1903-1994) & 66 & 24 & 26 & 32 & 32 & 36 \\
\hline & R.A.K. Frisch (1895-1973) & 74 & 28 & 31 & 37 & 31 & 38 \\
\hline 1970 & P.A. Samuelson (1915-) & 55 & 22 & 26 & 24 & 26 & 32 \\
\hline 1971 & S. Kuznets (1901-1985) & 70 & 20 & 25 & 29 & 29 & 40 \\
\hline \multirow[t]{2}{*}{1972} & J.R. Hicks (1904-1989) & 68 & 24 & $22^{\mathrm{a}}$ & 28 & $30 *$ & 34 \\
\hline & K.J. Arrow (1921-) & 51 & 28 & 30 & 30 & 28 & 30 \\
\hline 1973 & W.W. Leontief (1906-) & 67 & 19 & 22 & 27 & 25 & 35 \\
\hline \multirow[t]{2}{*}{1974} & K.G. M yrdal (1898-1987) & 76 & 29 & 29 & 32 & 40 & 46 \\
\hline & F.A. von Hayek (1899-1992) & 75 & 26 & 24 & 32 & 29 & 45 \\
\hline \multirow[t]{2}{*}{1975} & L.V. Kantorovich (1912-1986) & 63 & 18 & 23 & 27 & 26 & 47 \\
\hline & T.C. Koopmans (1910-1985) & 65 & $23 *$ & 26 & 35 & 32 & 41 \\
\hline 1976 & M. Friedman (1912-) & 64 & 23 & 34 & 25 & $25^{*}$ & 45 \\
\hline \multirow[t]{2}{*}{1977} & B.G. Ohlin (1899-1979) & 78 & 20 & 25 & 30 & 23 & 34 \\
\hline & J.E. M eade (1907-1995) & 70 & 26 & $23^{b}$ & $34^{*}$ & 40 & 48 \\
\hline 1978 & H.A. Simon (1916-) & 62 & 21 & 27 & 31 & 27 & 31 \\
\hline \multirow[t]{2}{*}{1979} & T.W. Schultz (1902-) & 77 & 30 & 28 & 43 & 28 & 59 \\
\hline & W.A. L ewis (1915-1991) & 64 & 24 & 22 & 34 & 35 & 39 \\
\hline 1980 & L.R. Klein (1920-) & 60 & 23 & 24 & 27 & 26 & 30 \\
\hline 1981 & J. Tobin (1918-) & 63 & 23 & 29 & 29 & 29 & 40 \\
\hline
\end{tabular}




\begin{tabular}{|c|c|c|c|c|c|c|c|}
\hline 1982 & G.J. Stigler (1911-1991) & 61 & 26 & 27 & 28 & $35 *$ & 50 \\
\hline 1983 & G. Debreu (1921-) & 62 & 30 & 35 & $33^{*}$ & 30 & 38 \\
\hline 1984 & J.R.N. Stone (1913-1991) & 71 & $23^{*}$ & 44 & $28 *$ & $27^{*}$ & $33^{*}$ \\
\hline $\begin{array}{l}\text { Nobel } \\
\text { year }\end{array}$ & Nobel laureate & $\begin{array}{l}\text { Nobel } \\
\text { Prize }\end{array}$ & $\begin{array}{c}\text { First } \\
\text { publication }\end{array}$ & $\mathrm{PhD}$ & $\begin{array}{c}\text { Breakthrough } \\
\text { publication }\end{array}$ & $\begin{array}{l}\text { Start N obel } \\
\text { Prize work }\end{array}$ & $\begin{array}{l}\text { M other lode } \\
\text { publication }\end{array}$ \\
\hline 1985 & F. Modigliani (1918-) & 67 & 26 & 26 & 26 & 26 & $36^{*}$ \\
\hline 1986 & J.M. Buchanan (1919-) & 67 & 30 & 29 & 31 & 30 & $43^{*}$ \\
\hline 1987 & R.M. Solow (1924-) & 63 & 27 & 27 & 32 & 31 & 32 \\
\hline 1988 & M.F.C. Allais (1911-) & 77 & 32 & 38 & 32 & 32 & 36 \\
\hline 1989 & T. Haavelmo (1911-) & 78 & 27 & 30 & 32 & 30 & 33 \\
\hline \multirow[t]{3}{*}{1990} & M.H. Miller (1923-) & 67 & $25^{*}$ & 29 & $35^{*}$ & $33 *$ & $35 *$ \\
\hline & H.M. M arkowitz (1927-) & 63 & 25 & 27 & 25 & 24 & 32 \\
\hline & W.F. Sharpe (1934-) & 56 & 27 & 27 & 29 & 27 & 30 \\
\hline 1991 & R.H. Coase (1910-) & 81 & 25 & 41 & 27 & 21 & 27 \\
\hline 1992 & G.S. Becker (1930-) & 62 & 22 & 25 & 27 & 25 & 34 \\
\hline \multirow[t]{2}{*}{1993} & R.H. Fogel (1926-) & 67 & 34 & 37 & 38 & 37 & $48^{*}$ \\
\hline & D.C. North (1920-) & 73 & 30 & 32 & 35 & 35 & 41 \\
\hline \multirow[t]{3}{*}{1994} & J.F. Nash (1928-) & 66 & 22 & 22 & 22 & 21 & 22 \\
\hline & R. Selten (1930-) & 64 & $29 *$ & 31 & 35 & 27 & 45 \\
\hline & J.C. Harsanyi (1920-) & 74 & 33 & 39 & 35 & 36 & 47 \\
\hline 1995 & R.E. Lucas Jr. (1937-) & 58 & $25^{*}$ & 27 & 30 & 33 & 35 \\
\hline \multirow[t]{2}{*}{1996} & J.A. M irrlees (1936-) & 60 & $26^{*}$ & 27 & 35 & 32 & 35 \\
\hline & W.S. Vickrey (1914-1996) & 82 & $24^{*}$ & 33 & 31 & 31 & 47 \\
\hline \multirow[t]{4}{*}{1997} & R.C. M erton (1944-) & 53 & 22 & 26 & 25 & 26 & 29 \\
\hline & M.S. Scholes (1941-) & 56 & $31^{*}$ & 28 & $31^{*}$ & $27 *$ & $32^{*}$ \\
\hline & M ean age & 668 & 255 & 286 & 308 & 293 & 379 \\
\hline & Standard deviation & 76 & 38 & 53 & 43 & 45 & 75 \\
\hline
\end{tabular}

* Co-authored publication.

In addition to these ages, the age at which the laureates received their PhD is mentioned. Most of the ages summed up in Table 1 are surrounded by uncertainty since it is almost impossible to name only one publication which marks the breakthrough of an author, but in all cases the next best publication that comes to mind of each and every author is at most one or two years within distance. In case of the age at which one strikes the motherlode and at which one starts working on the prizewinning work I have used the reports of the Nobel Memorial Prize committee in marking the outstanding work and in most cases I have used the short autobiographies which laureates submit to the $\mathrm{N}$ obel Prize committee once they have delivered their acceptance 
speech. ${ }^{4}$ If these reports did not reveal the landmarks in a career clearly, I have used biographies written by outstanding peers and the $\mathrm{SSCl}$ to separate chaff from wheat in the curriculum vitae.

Although the ages reported in Table 1 might give the impression of exactness they are not as exact and certain as they appear in black and white print. There are a number of factors which distort the measurement of the various ages. First of all, the Second World War makes the measurement of the most creative years difficult for a number of authors who were in the prime of their life around 1940. Samuelson's F oundations of E conomics Analysis appeared only in 1947, while his dissertation on which the book was based was finished in 1941, whereas most of the material written for the book was already several years old, "having been conceived and written primarily in 1937" (Samuelson, 1983, p. ix). Other examples of authors whose ambitions were stalled were Arrow, Fogel, and M eade. Nevertheless some found inspiration in these hard times, since the war effort in the US and UK and the subsequent reconstruction efforts entailed applied policy work which has led eminent economists like Tinbergen, Stone, and M eade to produce fundamental work. Wartimes and periods of civil turmoil also led some economists to flee their home country. Harsanyi left Hungary after the communist takeover and came, after some time to Stanford University, where he received his PhD in economics in 1959 at the ripe age of 39 (although he already had attained a PhD in philosophy at the age of 27 in Budapest).

A nother factor which blurs our measurement is the delay between the time of invention and publication. For some economists the refereeing process never caused any significant delay, but there are quite a number of Nobel laureates who have experienced the frustration of peer review at the beginning of their career. Bertil Ohlin produced his factor-proportions theorem in a submitted paper to the Economic J ournal in 1923, where it was rejected by the ruling editor John Maynard Keynes with the words "This amounts to nothing and should be refused, J.M.K.". Ten years later it appeared in his path-breaking book Interregional and International Trade (1933), work which earned him the Nobel Memorial Prize. Another delay in publication was endured by Robert Lucas with his path-breaking "Expectations and the Neutrality of Money" (1972), which was rejected by the American Economic Review in 1970 with remarks that the paper was "too mathematical". The same type of criticism was received by Black and Scholes who submitted their path breaking paper on option valuation to the Journal of Political Economy in October 1970, where it was promptly rejected because it had too much to do with finance and not enough with economics. The same reply came from the Review of Economics and Statistics. In January 1971 they rewrote their paper paying more attention to economics, and with the help of two Chicago economists - Eugene Fama and M erton M iller - they finally got their work accepted in the JPE issue of May/June 1973 (Bernstein, 1992, pp. 220-221). Other victims of the review process were M irrlees who derived in optimal taxation work in 1968 which finally saw its printed version in 1971, and William Sharpe who endured the frustrations of peer reviewing when he submitted his ideas about capital asset pricing in 1960. All these examples bear testimony to the case that the peer review system has its flaws as a filtering mechanism. Indeed, experimental tests as reported by Fölster (1995) show that the peer review system creates a bias towards incremental development of existing methods

4. In an appendix to this paper the complete list of publications is given. 
and against exploration of new methods. Of course, the alternative - a wise editor with a taste for good research who has the sole responsibility over acceptance and rejection - verges on the impossible, and the one example that springs to mind - J ohn M aynard Keynes - does not make an overriding case for accepting editordictatorship as the model of scientific judgement. Perhaps the examples of rejected papers by top-journals as summarized in Gans and Shepherd (1994) should not be stressed too much, since most of these papers appeared in journals of lesser stature but they eventually did become path-breaking.

$\mathrm{N}$ eedless to say, not all laureates endured these type of hardships. Some readily admit that their ideas needed time to ripen. An example of the latter may be found in Ronald Coase's fundamental contribution which he made at the tender age of 21, but it took him six years before his paper "The Nature of the Firm" was finally published. Language may also have been a barrier to entry in the international market for ideas. It took some time before the contributions by Kantorovich were translated into English and similar experiences, but less time-consuming, were those of Ohlin, M yrdal, Hayek and Allais.

Still, the biggest barrier in reviewing the publication record of $N$ obel laureates is the question of quality. Which publication marks a fundamental breakthrough? A possible standard for judging the quality of the work is the use of eponyms by fellow economists. Most Nobel laureates have achieved this feat. A few eponyms which spring to mind are: Hicks-neutral technical progress, the Arrow impossibility theorem, the L eontief-production function, K-spaces (named after Kantorovich), the Stolper-Samuel son theorem, the F-twist (named after Friedman), the Heckscher-Ohlin theorem, Tobit-estimation, the Stone age of consumption analysis (because of the simple linear form of the expenditure consumption model), the Modigliani-M iller theorem, the Solow residual, the Allais paradox, the Haavelmo-effect, the Coase theorem, Nash-equilibrium, the Lucas critique and the Lucas supply function, and the Vickrey auction. But as Stephen Stigler's Law of Eponymy (1980) - inventions are never named after their inventor - suggests there is always a predecessor and an unfair amount of attention goes to the superstars. The M atthew Effect (M erton, 1973) is, however, one of those mechanisms which are part and parcel of science. Still, the use of eponyms as a measure of quality is obviously not going to be an adequate measuring rod. On the one hand, certain groups of economists are quite inventive in tagging names to new ideas or methods. Just think of the endless eponymized econometric test statistics. A lthough these tests have sharpened the process of hypothesis testing in principle, they can hardly be interpreted as quantum leaps in economic science. On the other hand, quite a number of economics laureates do not possess a single eponym, even though they have enriched the literature with new words or abbreviation such as: the chain store paradox (Selten), CAPM (Sharpe), bounded rationality (Simon), human capital (Schultz), the distinction between instruments and goals of economic policy (Tinbergen, Frisch), and the method of simultaneous estimation (Haavelmo). Clearly, eponyms are not an adequate measure of scientific importance or quality.

A nother subjective element in the assessment of quality may be the divergence between what the $\mathrm{N}$ obel committee finds important and what the Nobel laureate himself finds important. At the end of his life J ohn Hicks did not think much of his general equilibrium work, as summed up in Value and Capital. This particular type of work earned him a Nobel Prize in 1972 together with Kenneth Arrow. Afterwards, he 
regretted the way his mathematical work turned out: "A lot of these mathematical models, including some of my own, are really terribly much in the air. They have lost their feet off the ground." (Klamer, 1989, p. 180). Instead of his efforts on general equilibrium analyses he found his book A Theory of Economic History, written at the age of 64 , his best piece of work. In a conversation he admitted that he would even have preferred that the Nobel Prize had been awarded him for this book (Klamer, 1989, p. 175n).

D espite these drawbacks, there are a number of stylized facts to be discerned from Table 1 . The most striking aspect of Table 1 is perhaps the young age at which most economists start publishing, although we hasten to add that it is not a necessary condition for future brilliance. Most laureates start publishing well before they have finished their dissertation. The latter finding may be a result of the fact that Europeans had in the past other standards with respect to writing a PhD. For instance, Coase and Stone finished their PhD at the ripe age of 44 and 41, respectively and two other English laureates - Hicks and Meade - have never even attained their doctorate and just started their career with their M A. The status of a PhD is also on the continent of Europe somewhat different: Reinhard Selten also wrote at the relative old age of 38 his dissertation in economics (although he had written a mathematics dissertation 7 years earlier), Gerard Debreu wrote his dissertation at 35 and his teacher A llais at 38. The age at which one writes a dissertation is therefore not going to be a good indication of future eminence. ${ }^{5} \mathrm{H}$ owever, the age at which one starts doing Nobel Prize work, the age at which at one earns international recognition and the age at which one has become a household name may very well be better indicators. One reason for distinguishing between these measures is that some laureates have received recognition well before they started their prize winning work. Notable examples are Tjalling K oopmans who first studied questions of (simultaneous) estimation, later switching to operation research (or as is was called then: activity analysis) and optimal growth theory, work which earned him the Nobel Prize together with Kantorovich. A nother fine example is Milton Friedman who is nowadays better known for his theories on consumption and money and not his earlier yet fundamental work on statistics.

A variable not mentioned so far is the age at which the $\mathrm{N}$ obel economists wrote their last fundamental publication. In order to pinpoint the exact date of this publication the Nobel committee reports in conjunction with the citation rate of publications in order to determine the last fundamental hit. ${ }^{6}$ We would expect that measurement of the last fundamental publication to be clouded by substantial uncertainty, because the younger laureates are still alive and publishing and have not in the least finished their career. Still, for the older

5. The fact that both Dutchmen Jan Tinbergen and Tjalling Koopmans wrote their PhD at the age of 26 is also not an indication that things were better in the low countries. Tinbergen and Koopmans were both physics students and physics had at that time a much higher scientific standard than economics, which was still a young discipline with very few students. Their fellow colleagueas in economics restricted themselves to discussing topics in economic policy and monetary economics in the lingo of the German historical school or the Austrian school.

6. The Social Science Citation Index (SSCI) can, of course, not be used for every Nobel laureate as the older laureates face the disadvantage of the short SSCl-sample period, which starts in 1966 and which would distort the measurement of impact. 
generation this variable might give some indication of the length of a creative working life. ${ }^{7}$

In Table 2 the contents of Table 1 are summarized as the average career of a Nobel economist, together with a test of generational differences. A number of elements stand out in Table 2. Although most N obel laureates go on publishing well beyond the year in which they were awarded the N obel Prize, the quality of their publications seems to drop quite rapidly. On average they have contributed their last important publication five years before the Nobel recognition. There is however the possibility that this characteristic is an artefact. If the true age at which one publishes the last fundamental publication (67 years of the old generation) and at which one earns the Nobel Prize (63 years of the younger generation), then the conclusion of creative burnout before the $\mathrm{N}$ obel date does not seem warranted. One can certainly make a case for the age of 67 as the true age at which one publishes the last fundamental piece of economics, since the old generation has completed its career either by passed away or - in the terminology of Beard - by entering the wooden decade of their career. The young generation is still actively engaged in the publishing game. To ascribe truth to the age of 63 as the year in which one generally earns Nobel recognition is a more doubtful affair since the age at which one receives a Nobel award for a particular idea does not seem to follow a clear trend. However, the fact that the younger generation finishes its motherlode publication five years earlier than the older generation makes recognition five years earlier than the older generation more likely. The recognition difference is however nine years, which still leaves four years unexplained. ${ }^{8}$

\section{Table 2: The average career of a Nobel E conomist}

\begin{tabular}{lccc}
\hline \multirow{2}{*}{ Points in career } & \multicolumn{3}{c}{ A ge (standard error of means between brackets) } \\
\cline { 2 - 4 } & Generation < 1915 & Generation $\geq 1915$ & All laureates \\
\hline First publication & $24.6(0.86)$ & $26.3(0.79)$ & $25.5(0.59)$ \\
PhD (or highest degree) & $29.0(1.48)$ & $28.3(0.88)$ & $28.6(0.82)$ \\
Starting N obel Prize winning work & $29.4(1.11)$ & $29.2(0.88)$ & $29.3(0.69)$ \\
International breakthrough & $31.4(0.98)$ & $30.4(0.89)$ & $30.8(0.66)$ \\
The motherlode publication & $40.7^{\mathrm{a}}(1.79)$ & $35.5^{\mathrm{a}}(1.33)$ & $37.9(1.15)$ \\
L ast fundamental publication & $66.5^{\mathrm{b}}(2.12)$ & $57.0^{\mathrm{b}}(2.03)$ & $61.3(1.63)$ \\
Receiving the Nobel Prize & $72.3^{\mathrm{b}}(1.34)$ & $62.3^{\mathrm{b}}(1.21)$ & $66.8(1.18)$ \\
\hline N umber of cases & 19 & 23 & 42 \\
\hline
\end{tabular}

(a) Rejection of equality of generational means at $5 \%$ significance level; (b) idem at $1 \%$ significance level.

7. A possible disturbing factor - death at a relatively young age - does not come into play. The average life span of deceased laureates in economics is 82.2 years with 74 years (Kantorovich) as the shortest life span and 93 years (Hayek) as the longest life span.

8. Eliminating the extraordinary career of John $\mathrm{N}$ ash J r. from the sample of younger laureates does not make a difference. 
Besides the generational differences, the absence of differences between generations is perhaps a more important feature to note. The start in academic life remains remarkably stable over the two generations. Economics, it should be stressed, is truly a young man's game. The domination of youth is even more clearly illustrated if we compare the age distribution of $\mathrm{N}$ obel laureates in economics to those in chemistry, physics, and medicine/physiology, as in Table 3. This table not only confirms Beard's Law that 70 percent of al the work of the world is done before the age of 45 , in case of economics 80 percent of all Nobel work is done before the age of 45 and a 100 percent (!) of the genesis of the $N$ obel winning work can be traced before the age of 40. The science game in other disciplines does not appear to be so strongly tied to the efforts of young men as it does in economics, but it seems safe to say that also in other disciplines the chances of making a big discovery decrease quite rapidly once one is past the age of 45 .

The existence of substantial differences across the various disciplines can to some extent be explained. A priori one would expect such a difference to exist since the subject matter of the disciplines cited varies by the extent to which knowledge in a research field is codified. Codification is according to Zuckerman and M erton (1972, p. 507) is the "consolidation of empirical knowledge into succinct and interdependent theoretical formulations." Experience should be more of an asset in a less codified discipline or field than it is for the field in which scientists are led by some general ideas. M edicine and biology are typically fields in which the degree of empiricism is high and a priori one would expect the average age at which eminent scientists make their important discovery to be higher than that of, e.g. physicists and mathematicians. 
Table 3: Percentage of scientists in different age groups when doing Nobel prizewinning work: age at which one began and finished Nobel work

\begin{tabular}{|c|c|c|c|c|c|c|c|c|}
\hline \multirow[t]{2}{*}{ Age } & \multicolumn{2}{|c|}{ Economics } & \multicolumn{2}{|c|}{ Chemistry } & \multicolumn{2}{|c|}{ Physics } & \multicolumn{2}{|c|}{ Physiology/M edicine } \\
\hline & $\begin{array}{l}\text { Beginning } \\
\text { age }\end{array}$ & $\begin{array}{c}\text { Ending } \\
\text { age }\end{array}$ & $\begin{array}{l}\text { Beginning } \\
\text { age }\end{array}$ & $\begin{array}{c}\text { Ending } \\
\text { age }\end{array}$ & $\begin{array}{c}\text { Beginning } \\
\text { age }\end{array}$ & $\begin{array}{c}\text { Ending } \\
\text { age }\end{array}$ & $\begin{array}{l}\text { Beginning } \\
\text { age }\end{array}$ & $\begin{array}{c}\text { Ending } \\
\text { age }\end{array}$ \\
\hline $21-25$ & 167 & 24 & 19.5 & 0.0 & 13.5 & 2.8 & 14.2 & 0.6 \\
\hline $26-30$ & 476 & 119 & 30.5 & 5.9 & 29.8 & 12.1 & 27.7 & 3.2 \\
\hline $31-35$ & 262 & 333 & 31.4 & 13.6 & 21.3 & 23.4 & 26.5 & 12.3 \\
\hline $36-40$ & 96 & 191 & 7.6 & 18.6 & 18.4 & 17.0 & 16.8 & 25.2 \\
\hline $41-45$ & 0.0 & 143 & 5.9 & 18.6 & 8.5 & 24.1 & 7.8 & 12.9 \\
\hline $46-50$ & 0.0 & 157 & 1.7 & 19.5 & 6.4 & 11.3 & 3.2 & 20.0 \\
\hline $51-55$ & 0.0 & 0.0 & 1.7 & 13.6 & 0.7 & 5.7 & 2.6 & 12.9 \\
\hline $56-60$ & 0.0 & 24 & 0.8 & 5.9 & 1.4 & 2.1 & 0.0 & 3.9 \\
\hline $61-65$ & 0.0 & 0.0 & 0.8 & 4.2 & 0.0 & 1.4 & 1.3 & 9.0 \\
\hline $\begin{array}{l}\text { M ean } \\
\text { age }\end{array}$ & 293 & 379 & 31.6 & 43.8 & 33.1 & 39.2 & 33.2 & 44.7 \\
\hline $\begin{array}{l}\text { M edian } \\
\text { age }\end{array}$ & 29.0 & 36.0 & 30.5 & 43.0 & 31.0 & 39.0 & 32.0 & 44.0 \\
\hline $\begin{array}{l}\text { No. of } \\
\text { cases }\end{array}$ & 42 & & 118 & & 14 & & 15 & \\
\hline
\end{tabular}

(a) Ages for laureates in chemistry, physics and medicine between 1901-1992 as reported in Stephan and Levin (1993, p. 396).

The evidence presented in Table 3 is startling to some extent as it suggests that economists work in a highly codified field, even more codified than physics. To a certain degree this statement is true if one restricts one's attention to general equilibrium theory and econometric theory. To begin with, a number of economists came in from the exact sciences, such as Frisch, Tinbergen, Koopmans, Kantorovich, Mirrlees, Nash, Allais, and they explicitly used the principles they learned in theoretical physics and mathematics to deal with economic questions. At that time, this strategy proved to be useful and it probably will prove to be useful today since it is an acknowledged fact that outsiders enjoy the benefits of looking at economic problems in an unorthodox fashion. However, being an outsider comes quite naturally if one starts a research career at an early age. Without being fettered by the steps taken by intellectual predecessors young scientists or outsiders make fundamental contributions.

The bold statement that economics is just like physics is, however, blatantly wrong. As Robert Solow has put it recently: "the part of economics that is independent of history and social context is not only small but dull." (1997, p. 56). Another reason is that economics as a science works differently. Sciences like 
mathematics and physics have enjoyed far more competition on clearly delineated research fields. Economic science is divided into ever smaller sub disciplines in which one or two giants dominate the field and this might give the impression that economics is a highly codified field (Frey and Eichenberger, 1997, make a comparable observation). This difference in scientific practice is to some extent displayed in the average number scientists who are awarded the Nobel Prize. The average number of $\mathrm{N}$ obel laureates who have to share the prize for the period 1969-1996 is 2.4 for physiology/medicine, 2.2 for physics, whereas the economists lag behind with an average of 1.4 laureates. ${ }^{9}$ There is another difference between economics and physics: in physics the value of an idea is easier established than economics, and mainly for one big reason: physics deals with nature and economics with human nature, the latter is far more difficult to model and predict. This difference is also reflected in the age at which one is awarded a Nobel Prize. The average age for physicists is 52 , whereas the comparable age for economists is 67 . Or to make the difference even more clearer: the youngest economics laureate is Kenneth Arrow who received the Nobel Prize at the age of 51. The youngest Nobel laureate in physics is William Lawrence Bragg, who was 25 years old when he received the N obel Prize in 1915 together with his father William Henry Bragg.

\section{But is A ge that Important?}

A II N obel laureates share the character trait of eminent scientists that they started their career at a relatively young age, and they generally started the work which earned them the Nobel Prize mostly in the golden age of life - the thirties. But, I hear the starlets cry, quite a large number of scientists started young and they never made the grade. Of course, one does not receive a Nobel Prize for being prolific, popular or for being a bright young man. Persons (or institutions) receive the Nobel Prize, who, in the words of Alfred N obel, "during the preceding year, shall have conferred the greatest benefit on mankind." Although, the prize in economics is not a genuine Nobel Prize but a Nobel Prize sponsored by the Central Bank of Sweden in memory of Alfred Nobel, the award rules are the same. The statutes prescribe that "the Prize shall be awarded annually to a person who has carried out a work in economic science of the eminent significance expressed in the Will of Alfred Nobel drawn up on November 1927, 1895." (Lindbeck, 1985, p. 38). But if age is not a good predictor of future creativity, what is? The literature on the sociology and economics of science comes up with a number of reasons. The three most important factors amount to the fact that: (i) Nobel laureates have networks which allows them to keep in touch with the frontiers of science; (ii) they focus on fundamental problems; and (iii) they have an independent mind.

9. The average number of laureates for the Fields $M$ edal in mathematics, a prize which serves a comparable function as the Nobel Prize, for the same period is 3.4. 


\section{N etworks}

E conomic science is not a matter of individual rationality, it is also a social and cultural matter. It is commonly perceived that networks matter in the dissemination of knowledge. For instance, Cox and Chung (1991) report that for the period 1963-1988 more than half of the contributions (i.e. 54 percent) in the top 20 economics journals was written by authors who graduated at the top three graduate schools: Harvard, M IT and Chicago. A lthough this concentration is seen as evidence of favouritism, based on the fact that editorship of top journals is mostly in the hands of authors situated at these top institutions, this does not appear to be the case as recent evidence has come available. Laband and Piette (1994) show that editors use their professional connections to capture high-impact papers for publication. Smart and Waldfogel (1996) go even further by documenting editorial bias in favour of authors who are situated outside the top institutions.

\section{Table 4: The right place at the right time}

\begin{tabular}{|c|c|c|c|}
\hline $\begin{array}{l}\text { Nationality (by } \\
\text { country of birth) }\end{array}$ & $\begin{array}{l}\text { University granting the PhD (or } \\
\text { highest degree) }\end{array}$ & $\begin{array}{l}\text { University with start Nobel } \\
\text { Prize winning work }\end{array}$ & $\begin{array}{l}\text { University with the motherlode } \\
\text { publication }\end{array}$ \\
\hline 1. USA (20) & 1. University of Chicago (7) & 1. University of Chicago (5) & 1. University of Chicago (7) \\
\hline 2. UK (5) & 2. Colombia University (4) & 2. LSE (4) & 2. Carnegie-M ellon (4) \\
\hline 3. Russia (3) & Harvard University (4) & 3. Harvard U niversity (3) & M IT (4) \\
\hline 4. France (2) & 4. Cambridge U niversity (2) & MIT (3) & 4. LSE (3) \\
\hline N etherlands (2) & Johns Hopkins U niversity (2) & 5. UC Berkeley (2) & 5. Cambridge U niversity (2) \\
\hline Norway (2) & L eiden University (2) & Carnegie-M ellon (2) & Harvard U niversity (2) \\
\hline \multirow[t]{4}{*}{ Sweden (2) } & LSE (2) & NBER (2) & Stockholm U niversity (2) \\
\hline & MIT. (2) & RAND (2) & University of Washington (2) \\
\hline & Oxford U niversity (2) & & \\
\hline & Stockholm University (2) & & \\
\hline
\end{tabular}

Table 4 shows that US institutions ${ }^{10}$, especially the University of Chicago, have been quite successful in nurturing risk loving talent. The logical question that pops up is: why has the University of Chicago been so successful? Heterodox economists who like conspiracy theories would answer that it neoclassical economics is in vogue and best place to learn and teach neoclassical economics is Chicago. This is the easy answer which can be easily refuted since the selection procedure of the Nobel committee is rather strict and does not seem exceedingly vulnerable to award fashions in economics. ${ }^{11} \mathrm{~A}$ more plausible answer is to be found in research

10. For the record, 29 of the 42 breakthroughs were achieved in the US/Canada and 7 in the U.K.. In other words, 36 of the 42 ideas were achieved in the Anglo-Saxon World.

11. Of course, there might be a grain of truth in attaching some weight to networks in awarding prizes, since all living Nobel laureates participate in nominating candidates for the Nobel Prize. Considering the fact that of 
culture of Chicago as summed up aptly by The Economist: "The combination of a fondness for dissent, an antiestablishment culture and a distaste for public-policy research has created an environment in which economic research is geared towards the slaying of sacred cows." (M arch 30, 1996).

H owever, one should not underestimate the element of chance and path-dependence in the sustenance of a Chicago School in economics, especially the brain drain of J ewish scientists spurred by the Second World War, by some coined with the phrase 'Hitler's Gift to A merican Science' (Zuckerman, 1977). Frey and Pommerehne (1988) show that the US indeed is the dominant leader in economics. However, before the W orld War, the center of economics could be found in Europe, especially the UK, France, A ustria and Germany. The emigration of, for example, Jacob M arschak and Tjalling Koopmans to the US was a strike of good luck for Chicago and the Cowles Commission.

\section{Problem finders}

Although economics and science in general is portrayed as a race for priority, there is I think something else which makes $\mathrm{N}$ obel laureates stand out as original minds, viz. their ability to find and formulate problems. It was the sociologist Robert K. M erton (1973, p. 453) who, in reviewing interviews held with Nobel laureates, pointed out that these outstanding scientists repeatedly stressed the importance of problem-finding, not only problem-solving. Nobel laureates, as M erton interpreted it, "uniformly express the conviction that what matters most is in their work is a developing sense of taste, of judgement, in seizing upon problems that are of fundamental importance." The same characteristic applies equally to leading economists. For instance, it was M aynard Keynes who in a letter dated July 4, 1938, to Harrod wrote "Good economists are scarce because the gift for using 'vigilant observation' to choose good models, although it does not require a highly specialised intellectual technique, appears to be a very rare one." (Keynes, 1973, p. 296). A nd similar statements can be collected from the work of, e.g. Stigler, Solow and Samuelson. The importance of vision or an intuition for "the right kind of question" reappears in every biography of an economist of some stature. Robert Solow (1997, p. 56) laments the approach of economists who imitate theoretical physicists and suggests that "there is a tendency to undervalue keen observation and shrewd generalization, virtues that I think are more usually practised by biologists." Or just listen to what Robert Lucas has to say when he tries to explain why most academics do not make lasting contributions: "People are asking the wrong questions; they are taking questions from Washington, rather than thinking about what's puzzling them or taking more scientific points of view." (Cited in Klamer, 1984, p. 52). The idea that all good questions should be relevant to problems faced by the government of the day is indeed the biggest mistake to be made in selecting problems. If one browses through the vitae of Nobel laureates, the applied work stands out as some curiosity of a distant past, whereas the fundamental papers are still worth the read. The best work of Samuelson, Stigler, Solow, Nash, or Debreu was inspired by a desire to improve the way we think the world works. Although quite a number of economists,

the $40 \mathrm{~N}$ obel economics laureates, twenty of them have been affiliated during their career with the University of Chicago. See for a peek into the selection procedure, Lindbeck (1985). 
such as Tinbergen, Solow, Tobin and Samuelson, claimed that they wanted to change the world the policy questions of the 'madmen in high places' seemed to be of secondary importance in their scientific endeavours.

\section{Independent minds and writers}

Thomas $M$ ann once settled the question whether lone wolves are better by asserting: "Solitude gives birth to the original in us, to beauty unfamiliar and perilous - to poetry. But also, it gives birth to the opposite: to the perverse, the illicit, the absurd." Implicit in this statement is that two or more authors may circumvent the risk of making big mistakes, while the author taking on a scientific problem single-handedly enjoys the benefits of risk taking but also the perils, viz. becoming the fool of the scientific community. M ost innovations are judged before publication by peers and is well-known the peer review system can make the error of discarding publications which are basically sound and innovative (see Shepherd, 1995) as well as the mistake of accepting publications which err. As the editor of the Economic Journal John M aynard Keynes could make many an author's life hell. For instance, his prejudiced rejections delayed the career of such eminent economists as $\mathrm{K}$ alecki and Harrod considerably. Fortunately it did not hamper the career of Bertil Ohlin as we saw earlier in section 2. Furthermore in discussing Tinbergen's path-breaking work on business cycles in the Economic J ournal, he described the econometrics of Tinbergen as black magic, but then again at that time Keynes had the attitude of a mandarin who could bluff his way in any subject under the sun (see the interview with Stone in Pesaran, 1991). Still the articles cited in Shepherd (1995) are almost without exception solo products. There is, of course, the problem that multi-authorship is a sign of recent decades, and 90 percent of the Nobel laureates of Table 1 produced their motherlode publications before 1970. The youngest innovation dates from 1975.

The surprising thing which jumps of the page of Table 1 is that most path-breaking publications are written alone, contrary to the trend in academia where co-authored papers have become the rule (Hudson, 1996). ${ }^{12}$ To a certain extent this observation can be shaded by the selection of publications on which Table 1 is based. The solo publication of Samuelson (1939) could be replaced by his seminal paper with Wolfgang Stolper (1941). The same applies to Arrow who wrote equally important papers with Gerard Debreu, Frank $\mathrm{H}$ ahn and $\mathrm{M}$ ordecai Kurz on general equilibrium theory and Milton Friedman collaborated with a number of great minds (Stigler, Savage, and Kuznets) wrote a much cited book on monetary history with A nna Schwart (1963) and an influential book on independent professional practices with Kuznets (1945). George Stigler is also an excellent example, coauthoring a paper with Gary Becker on the issue of accounting for tastes in economic theory (1977), but by and large most of his path-breaking publications were written alone and some $\mathrm{N}$ obel laureates were typical lone wolves in their writing activities. Just think of a number of the seminal publications of Jan Tinbergen, Maurice Allais, Ragnar Frisch, Trygve Haavelmo, Paul Samuelson, Friedrich

12. As a reminder of this trend: the most recent figures for three top-journals: the percentage of co-authored papers in 1996 was $64.2 \%$ for the American Economic Review, $67.4 \%$ for the J ournal of Political Economy and $58.6 \%$ for Econometrica. 
Hayek and M ilton F riedman and one must admit that these publications were written single-handedly.

There is, of course, the problem that multi-authorship has become common working practice amongst economists in the past few decades. The Nobel laureates of Table 1 produced 90 percent of their most important work before 1970. The lone wolf-result is, however, not some outlier in the field of science studies. L aband (1986) showed that of the 16 classic economic articles which appeared in 1974-1976 two were written by a team of authors (in both cases the coauthored papers were written by Sargent and W allace), the rest of the top articles were solo productions. Van Dalen (1997) provides evidence of the distribution of important papers produced by the total population of Dutch economists. The majority of these publications (74 percent) was written alone and this result is remarkably stable across generations of economists.

It is, of course, an entire different matter who intellectually influenced these publications by conversation, debate or in writing letters and publications. The University of Chicago with dominant figures such as Frank Knight and Jacob Viner and later on equally influential characters such as F riedman, Hayek, Fogel, M iller and Lucas, the Cowles Foundation, first at Chicago and later one at Y ale (Tobin, Koopmans, Haavelmo, Debreu, Klein, Modigliani, Simon, Markowitz, Arrow), the League of Nations in Geneva (T inbergen, Haberler, Koopmans, Polak, M eade, Stone) or the London School of Economics (Coase, Hayek, M eade, Hicks, L ewis) offered breeding ground for path-breaking ideas. ${ }^{13}$

There are a number of reasons why path-breaking papers were written alone. For one reason because a number of authors came from outside the field: Tinbergen, Kantorovich, Koopmans, Mirrlees, A rrow, Sharpe, Lucas, Selten, Nash and Allais. To collaborate with other fine minds was impossible for reasons of geographical distance or simply ignorance. Tinbergen was not aware of the probability approach as developed by Haavelmo in Harvard when he went on to apply his modelling work to economic policy. A second reason can be found in the stage of the economic science. The number of academic economists was a far smaller number than today. Furthermore, geographical distance is no longer an overriding burden with the emergence of fax machines and electronic mail. As shown by M cDowell and M elvin (1983), the growing number of economists to collaborate with partly explains the rise in multi-authored papers.

A third reason can be found in the literature on scientific productivity. Co-authorship is a way to increase productivity because knowledge depreciates as time passes by and economics has become more and more specialised and technical. The scientist who can genuinely say that he is a 'master of his subject', in other words, the economist who has a firm grip on the entire span of economic science, belongs to the days of $M$ arshall, Pigou and Keynes. Furthermore, incentives in academia seem to be geared towards collaboration. Liebowitz and Palmer (1988) report results of a survey of US department chairs that indicate that chairmen assign a weight to coauthored papers that exceeds $1 / n$ (with $n$ being the number of authors). There is, however, evidence which does not lend support to making the general statement that incentives are geared towards collaboration. Sauer (1988) found that there are substantial returns to quality in research, however, the

13. It should also be stressed that an academic environment is not a necessary condition for initiating fundamental work. The RAND corporation and the NBER have proven in the past to be good breeding grounds for fundamental researchers. 
weight for coauthored work is not much different from 1/n. McDowell and Smith (1992) failed to reject the hypothesis of equal weighting for single and multiple authorship, but they did find that top institutions discount coauthorship more than lower ranked institutions. Perhaps these anomalous findings are related to the microeconomics of research collaboration. As Laband and Piette (1995) show, the production of influential publications typically involves similarly-aged colleagues with complementary skills (albeit measured by the cumulative stock of citations). The mentor-protege type of collaboration does in their opinion not prove to be very productive. Of course, productivity may not be much of a worry to a scientist if his reward is not explicitly or implicitly related to his scientific productivity. European universities have been known for the absence of such a relationship and the eminent scientists who made their mark achieved this out the most important incentive available to a scientists: pure curiosity. N eedless to say, this system in which efforts were hardly monitored and in which appoints were made on the basis of who you knew produced also a considerable number of errors and only the research groups who enjoyed the guidance of researchers with a taste for talent and making connections could thrive (see, e.g. V an Dalen and Klamer, 1996 and 1997).

A fourth reason for this anomalous finding is the increasing degree of specialisation in economic science; a drawback which shows much resemblance with the welfare costs of specialisation in economic policy advice (cf. Swank, Letterie and Van Dalen, 1997). By splitting up the analysis of a complex phenomenon along the lines of each distinguishing element, information is lost which leads to a deadweight loss which can be circumvented by keeping the analysis in the hands of only one adviser or, in our case, researcher. This is not to say that specialisation is without benefits, but apparently the costs of specialisation in producing basic knowledge exceed the benefits.

\section{Conclusion}

E conomics is a young man's game. M ost economists achieve a breakthrough in academia in their twenties, hitting the motherlode of their efforts at the end of their thirties. The reason for this age-relatedness can be traced to the deeper character traits of the successful scientist. The average $\mathrm{N}$ obel laureate is equipped with the following blessings: talent, an independent or an outsiders' mind $^{14}$, a love for risky projects, a nose for being at the right place at the right time, the gift to see fundamental problems and, last but not least, luck. Luck, talent, vision and the seeking of kindred spirits and times are not necessarily tied to age, but with some imagination one can see why the young scientist has an advantage over the older scientist when it comes to

14. Scientists with a Jewish background seem to be relatively well-endowed with these character traits. An exceedingly large number of $\mathrm{N}$ obel $\mathrm{L}$ aureates often turn out to be Jewish or of J ewish origin. 45 percent of the laureates in economics whose religion could be traced (31) were Jewish or of Jewish origin. This fact was noted earlier by Zuckerman (1977) who argued that a large part of the overrepresentation can be explained by selection. Others ascribe the overrepresentation to the fact that Jews have no strong ties to the culture of a country, their mind is more attuned to considering issues which exceed the particular. M ore plausible reasons are that J ews have strong family ties and networks and they stress the importance of higher learning. 
taking risks and having a fresh mind. Of course, none of these elements form an instant recipe for success. It takes all sorts to push the frontier of economic science outwards and knowing where that research frontier lies and how it can be shifted defies the logic of creative science. "If you're so smart why don't you have a Nobel Prize?" is perhaps the right question to ask. But even under the ideal circumstances of possession of a Nobel Memorial medal does not give one the power to articulate the fundamental problems which will change a science. As Robert Lucas once answered this impossible question: "The research frontier? That's too hard a question. If I knew the answer, I'd be doing it." (The Region, June 1993)

\section{References}

Backhouse, Roger, Roger M iddleton, and Keith Tribe, 1997, "Economics is What Economists Do", but What Do the Numbers Tell Us?, Paper presented for Annual History of Economic Thought Conference, University of Bristol, 3-5 September 1997.

Beard, George M., 1874, Legal Responsibility in Old Age, Russells, N ew Y ork.

Beard, George M ., 1881, American Nervousness, Its Causes and Consequences, Putnam, New Y ork.

Bernstein, Peter, 1992, Capital Ideas, The Improbable O rigins of M odern Wallstreet, Free Press, N ew Y ork.

Colander, David C., 1989, Research on the Economics Profession, J ournal of Economic Perspectives, 3, 137 148.

Cole, Stepen, 1979, A ge and Scientific Performance, American J ournal of Sociology, 84, 958-977.

Cox, Raymond A.K., and Kee H. Chung, 1991, Patterns of Research Output and Author Concentration in the Economics Literature, Review of Economics and Statistics, 740-747.

Dalen, Hendrik P. van, 1997, Measuring Giants and Dwarfs - Assessing the Quality of Economists, Scientometrics, 38, 231-252.

Dalen, Hendrik P. van, and A rjo Klamer, 1996, Telgen van Tinbergen, Het verhaal van de Nederlandse economen, Balans, A msterdam.

Dalen, Hendrik P. van, and A rjo Klamer, 1997, Blood is Thicker than W ater - Economists and the Tinbergen Legacy, in: P.A.G. van Bergeijk et al., Economic Science and Practice, Edward Elgar, Cheltenham.

Fölster, S., 1995, The Perils of Peer Review in Economics and Other Sciences, Journal of Evolutionary Economics, 5, 43-57.

Frey, Bruno S., and Reiner Eichenberger, 1997, Economists: First Semester, High Flyers and UFO's, in: P.A.G. van Bergeijk et al., Economic Science and Practice, Edward Elgar, Cheltenham.

F rey, Bruno S., and Werner W. Pommerehne, 1988, The A merican Domination among Eminent Economists, Scientometrics, 14, 97-110.

Gans, Joshua S., and George B. Shepherd, 1994, How A re the Mighty Fallen: Rejected Classic A rticles by Leading Economists, J ournal of Economic Perspectives, 8, 165-179. 
Goodwin, Thomas H., and Raymond D. Sauer, 1995, Life Cyle Productivity in A cademic Research: Evidence from Cumulative Publication Histories of Academic Economists, Southern Economic Journal, 62, 728-743.

Hayek, F.A., 1978, Two Types of M ind, in: F.A. Hayek, New Studies in Philosophy, Politics, Economics and the History of Ideas, U niversity of Chicago Press, Chicago.

Hudson, John, 1996, Trends in M ulti-A uthored Papers in Economics, J ournal of Economic Perspectives, 10, 153-158.

K enny, Lawrence W., and Roger E. Studley, 1995, Economists's Salaries and Lifetime Productivity, Southern E conomic J ournal, 62, 382-393.

Keynes, John Maynard, 1973, The General Theory and After, in: Donald M oggridge (ed.), The Collected Writings of J ohn M aynard Keynes, V ol. XIV, M acM illan, London.

Klamer, Arjo, 1984, The New Classical Macroeconomics, Conversations with the New Classical Economists and their Opponents, Harvester Press, Sussex.

K lamer, A rjo, 1989, An Accountant A mong Economists: Conversations with Sir John R. Hicks, Journal of Economic Perspectives, 3, 167-180.

Laband, D avid N., 1986, A rticle Popularity, Economic Inquiry, 25, 173-180.

Laband, David N., and M ichael J. Piette, 1994, Favoritism versus Search for Good Papers: Empirical Evidence Regarding the Behavior of J ournal Editors, J ournal of Political Economy, 102, 194-203.

Laband, David N., and Michael J. Piette, 1995, Team Production in Economics: Division of Labor or M entoring?, Labour Economics, 2, 33-40.

Lehman, Harvey C., 1953, Age and Achievement, Princeton U niversity Press, Princeton, NJ .

Liebowitz, Stanley J., and John P. Palmer, 1988, A ssessing A ssessments of E conomic Departments, Q uarterly Review of Economics and Business, 28, 88-113.

L indbeck, Assar, 1985, The Prize in Economic Science in M emory of Alfred N obel, J ournal of Economic Literature, 23, 37-56.

McDowell, John M., and Michael Melvin, 1983, The Determinants of Coauthorship: An Analysis of the Economics Literature, Review of Economics and Statistics, 65, 155-160.

M CD owell, John M., and Janet K. Smith, 1992, The Effect of Gender Sorting on Propensity to Coauthor: Implications for A cademic Promotion, Economic Inquiry, 30, 68-82.

M erton, Robert K., 1968, The Matthew Effect in Science, reprinted in: Robert K. Merton, 1973, The Sociology of Science, Theoretical and Empirical Investigations, University of Chicago Press, Chicago.

Oster ${ }_{n}$ Sharon, and Daniel S. Hamermesh, 1997, A ging and Productivity, Review of Economics and Statistics, forthcoming.

Pesaran, M. Hashem, 1991, The ET Interview: Professor Sir Richard Stone, Econometric Theory, 7, 85-123.

Samuelson, Paul A., 1983, Foundations of Economic Analysis, enlarged edition, originally published in 1947, $\mathrm{H}$ arvard U niversity Press, Cambridge, M ass. 
Sauer, Raymond D., 1988, Estimates of the Returns to Quality and Coauthorship in Economic Academia, J ournal of Political Economy, 96, 855-866.

Shepherd, George B. 1995, Rejected!, Leading E conomist Ponder the Publication Process, Sun Lakes.

Smart, Scott and Joel Waldfogel, 1996, A Citation-Based Test for Discrimination at Economics and Finance Journals, NBER W orking Paper no. 5460, Cambridge, M ass.

Solow, Robert M ., 1997, How Did Economics Get That Way and What Way Did It Get?, Daedalus, 126, 3958.

Stephan, Paula E., and Sharon G. Levin, 1993, A ge and the Nobel Prize Revisited, Scientometrics, 28, 387399.

Stigler, Stephen M., 1980, Stigler's L aw of Eponymy, Transactions of the New York Academy of Sciences, 39, 147-158.

Swank, Otto H., Wilko A. Letterie, and Hendrik P. van Dalen, 1997, An Economic Theory of Policy Advice, Tinbergen Institute Discussion Paper TI 97-090/1, Rotterdam.

Zuckerman, Harriet, 1977, Scientific Elite, Nobel Laureates in the United States, Free Press, London.

Zuckerman, Harriet, and Robert K. M erton, 1972, A ge, A ging, and Age Structure in Science, reprinted in: Robert K. M erton, 1973, The Sociology of Science, U niversity of Chicago Press, Chicago. 


\section{A ppendix: Biographical facts N obel laureates}

1.

Name:

Date born:

Died:

Nationality:

Religion:

PhD thesis:

A warded (jointly) in 1969 for

First publication:

Breakthrough publication:

Start award-winning research

M other lode publication:

L ast path-breaking publication:

U niversity with motherlode:

University with start:

Literature:

2.

N ame:

Date born:

Died:

Nationality:

Religion:

PhD thesis:

A warded (jointly) in 1969 for

First publication:

Breakthrough publication:

Start award-winning research

M other lode publication:

L ast path-breaking publication: U niversity with motherlode:

\author{
Jan Tinbergen \\ A pril 12, 1903 \\ June 9,1994 \\ Dutch
}

A gnostic, from Protestant background

1929, U niversity of L eiden

"For having developed and applied dynamic models for the analysis of economic processes."

1927, "Over mathematies-statistiese methoden voor konjunktuuronderzoek", De Economist, 76, 711-723.

1935, "A nnual Survey: Suggestions on Quantitative Business Cycle Theory," "E conometrica, 3, 241-308.

1935, "A nnual Survey: Suggestions on Quantitative Business Cycle Theory," E Econometrica, 3, 241-308.

1939, Statistical Testing of Business Cycle Theories, I, A M ethod and Its Apllications to Investment; and II, Business Cycles in the United States of America, 1919-1932, League of Nations, Geneva.

1975, Income Distribution: Analysis and Policies, NorthHolland, A msterdam.

Netherlands School of Economics (now: Erasmus University) Rotterdam; Central Bureau of Statistics, The Hague.

Netherlands School of Economics (now: Erasmus University) Rotterdam; Central Bureau of Statistics, The Hague.

J. Kol and P. de Wolff, 1993, Tinbergen's W ork: Change and Continuity, De Economist, 141, 1-28.

Ragnar A.K. Frisch

March 3, 1895

January 31, 1973

Norwegian

Jewish

1926, University of Oslo

"For having developed and applied dynamic models for the analysis of economic processes."

1923, "Remarque sur le calcul numerique des functions symmetriques elementaires", Norsk Matematisk Forenings Skrifter I, 14, 83-86.

1932, New Methods of Measuring Marginal U tility, Tübingen.

1926, "Sur un probleme d'economie pure", Norsk Matematisk Forenings Skrifter, 16, 1-40.

1933, "Propagation Problems and Impulse Problems in Dynamic Economics", in: Ecnoomic Essays in Honour of Gustav Cassel, George Allen \& Unwin, London. 1965, Theory of Production, Reidel Publ. Co., Dordrecht. Univerisity of Oslo 
U niversity with start:

L iterature:

3.

N ame:

D ate born:

Died:

N ationality:

Religion:

PhD thesis:

A warded in 1970 for

First publication:

B reakthrough publication:

Start award-winning research

M other lode:

L ast path-breaking publication:

U niversity with motherlode: U niversity with start:

L iterature:

4.

N ame:

$D$ ate born:

Died:

N ationality:

Religion:

PhD thesis:

A warded in 1971 for:

First publication:

Breakthrough publication:

Start award-winning research
Univerisity of Oslo

O. Bjerkholt (ed.), 1995, Foundations of Modern Econometrics, The Selected Essays of Ragnar Frisch, Edward Elgar, Aldershot.

Paul A. Samuelson

M ay 15, 1915

U.S.

Jewish

1941, H arvard U niversity

"For the scientific work through which he has developed static and dynamic economic theory and actively contributed to raising the level of analysis in economic science."

1937, "A Note on Measurement of Utility", Review of Economics and Stastistics, 4, 155-161.

1939, "Interaction between the Multiplier A nalysis and the Principle of Acceleration, Review of Economics and Statistics, 21, 75-78.

1941, The Operational Significance of Economic Theory, Phd Thesis, Harvard.

1947, Foundations of Economic Analysis, Harvard University Press, Cambridge, M ass.

1976, The Optimum Growth Rate for Population: A greement and Evaluations, International Economic Review, 17, 516-525.

M.I.T.

Harvard

A. Lindbeck, 1970, Paul A nthony Samuelson's

Contribution to Economics, Swedish Journal of Economics, 341-354.

Simon K uznets

A pril 30, 1901

July 10, 1985

Russian, later U.S.

Jewish

1926, Columbia University

"For his empirically founded interpretation of economic growth which has led to new and deepened insight into the economic and social structure and process of development." 1921, "M oney Wages of Factory Employees in Kharkov, 1920" (in Russian), in: Materials on Labour Statistics of U kraine, K harkov, Central Soviet of Trade Union, Southern Bureau, Division of Statistics.

1930, Secular Movements in Production and Prices: Their Nature and Their Bearing Upon Cyclical Fluctuations, Boston.

1930, Secular Movements in Production and Prices: Their Nature and Their Bearing Upon Cyclical Fluctuations, Boston. 
M other lode publication:

L ast path-breaking publication:

University with motherlode:

U niversity with start:

Literature:

5.

N ame:

Date born:

Died:

Nationality:

Religion:

PhD thesis:

A warded (jointly) in 1972 for:

First publication:

Breakthrough publication:

Start award-winning research

M other lode publication:

L ast path-breaking publication: U niversity with motherlode:

U niversity with start:

Literature:

6.

Name:

Date born:

Died:

N ationality:

Religion:

PhD thesis:

A warded (jointly) in 1972 for:

First publication:

Breakthrough publication:

Start award-winning research

M other lode publication:

L ast path-breaking publication:

U niversity with motherlode:

U niversity with start:
1941, National Income and Its Composition, 1919-1938, NBER, Cambridge, MA.

1976, "Demographic Aspects of the Size Distribution of Income: An Exploratory Essay", Economic Development and Cultural Change, 25, 1-94.

University of Pennsylvania

University of Pennsylvania

E. Lundberg, 1971, Simon Kuznets' Contribution to Economics, Swedish J ournal of E conomics, 444-461.

John R. Hicks, Sir

A pril 8, 1904

M ay 20, 1989

U.K.

Christian

1926 (BA) Oxford U niversity

"For their pioneering contributions to general economic equilibrium theory and welfare theory."

1928, "W age Fixing in the Building Industry", Economica.

1932, The Theory of Wages, M acM illan, London.

1934, (with R.G.D. Allen) "A Reconsideration of the Theory of V alue", Economica,

1938, Value and Capital, Oxford U niversity Press, Oxford.

1979, Causality in Economics, Basil Blackwell, Oxford.

Cambridge U niversity

London School of Economics

W.J. Baumol, 1972, John R. Hicks' Contribution to Economics, Swedish Journal of Economics, 503-527; A. Klamer, 1989, An Accountant A mong Economists: Conversations with Sir John R. Hicks, J ournal of Economic Perspectives, 3, 167-180.

Kenneth J. A rrow

A ugust 23, 1921

U.S.

Jewish

1951, Columbia University

"For their pioneering contributions to general economic equilibrium theory and welfare theory."

1949, "On the U se of Winds in Flight Planning", J ournal of Meteorology, 6, 150-159.

1951, Social Choice and Individual Values, Wiley, New Y ork.

1949, RAND memos on Social Choice and Individual $\checkmark$ alues.

1951, Social Choice and Individual Values, Wiley, New Y ork.

1982, "Risk Perception in Psychology and Economics", Economic Inquiry, 20, 1-9.

University of Chicago/RA ND

University of Chicago/RAND 
Literature:

7.

Name:

Date born:

Died:

Nationality:

Religion:

PhD thesis:

A warded in 1973 for:

First publication:

Breakthrough publication:

Start award-winning research

M other lode publication:

L ast path-breaking publication:

University with motherlode:

U niversity with start:

Literature:

8.

N ame:

$D$ ate born:

Died:

Nationality:

Religion:

PhD thesis:

A warded (jointly) in 1974 for:

First publication:

Breakthrough publication:

Start award-winning research

M other lode publication:

L ast path-breaking publication:

University with motherlode:
C.C. von Weizsacker, 1972, Kenneth A rrow's Contribution to E conomics, Swedish J ournal of E conomics, 488-502.

Wassily W. L eontief

A ugust 5, 1906

Russian, later U.S. (1931)

Eastern Orthodox

1928, U niversity of Berlin

"For the development of the input-output method and for its application to important economic problems."

1925, "Die Bilanz der Russischen Volkswirtschaft - Eine methodologische Untersuchung", Weltwirtschaftliches Archiv, 22, 338-344.

1933, "The U se of Indifference Curves in the A nalysis of Foreign Trade", Quarterly J ournal of Economics, 47, 493503.

1931, starting to formulate general equilibrium theory capable of empirical implementation, 1932 research grant for compilation of first input-output table of U.S. economy.

1941, The Structure of the American Economy, 1919-1929, $\mathrm{H}$ arvard U niversity Press, Cambridge, M ass.

1977, The Future of the World Economy - A U nited Nations Study, Oxford U niversity Press, Oxford.

Harvard University

NBER, N ew Y ork.

R. Dorfman, 1973, Wassily Leontief's Contribution to Economics, Swedish J ournal of Economics, 430-441.

K. Gunnar M yrdal

December 6, 1898

M ay 17, 1987

Swedish

Lutheran

1927, U niversity of Stockholm

"For their pioneering work in the theory of money and economic fluctuations and for their penetrating analysis of the interdependence of economic, social and institutional phenomena."

1927, Prisbidningsproblemet och foranderligheter (Pricing and the Change F actor), Stockholm, A Imqvist \& Wiksell.

1930, Vetenskap och politik i nationalekonomien, translated in 1953 in: The Political Element in the Development of Economic Theory, Harvard U niversity Press, Cambridge.

1938-1943, preparation for An American Dilemma: The Negro Problem and M odern Democracy.

1944, An American Dilemma: The Negro Problem and Modern Democracy, Harper Brothers, N ew Y ork.

1970, The Challenge of World Poverty: A World AntiPoverty Program in Outline, Pantheon Books, N ew Y ork. University of Stockholm 
U niversity with start:

L iterature:

9.

N ame:

D ate born:

Died:

N ationality:

Religion:

PhD thesis:

A warded (jointly) in 1974 for:

First publication:

Breakthrough publication: Start award-winning research

M other lode publication:

$\mathrm{L}$ ast path-breaking publication:

U niversity with motherlode:

U niversity with start:

L iterature:

10.

N ame:

D ate born:

Died:

N ationality:

Religion:

PhD thesis:

A warded (jointly) in 1975 for:

First publication:

Breakthrough publication:

Start award-winning research
Carnegie Corp.

L.G. Reynolds, 1974, Gunnar Myrdal's Contribution to Economics 1940-1970, Scandinavian J ournal of Economics, 479-497.

Friedrich $A$. von Hayek

M ay 8, 1899

$M$ arch 23, 1992

A ustrian, later British, U.S. and German

Catholic

1923, U niversity of V ienna (A ustria)

"For their pioneering work in the theory of money and economic fluctuations and for their penetrating analysis of the interdependence of economic, social and institutional phenomena."

1925, Die Wahrungspolitik der Vereinigten Staaten seit der Uberwindung der Krise von 1920, Zeitschrift für Volkswirtschaft und Sozialpolitik, N.S., 5.

1931, Prices and Production, London.

1928, Geldtheorie und Konjunkturtheorie, Hoelder-PichlerTempsky, Vienna.

1944, The Road to Serfdom, Routledge, London.

1976, Denationalization of Money, Institute of Economic Affairs, L ondon.

London School of Economics

London School of Economics

F. M achlup, 1974, Friedrich von Hayek's Contribution to Economics, Scandinavian Journal of Economics, 498-531; K. Puttaswaimaiah, 1995, Friedrich V on Hayek, in: Nobel Economists: Lives and Contributions, Indus Publ., New Delhi.

Leonid V. K antorovich

January 19, 1912

A pril 6, 1986

Russian

Jewish

1935, L eningrad State University

"For their contributions to the theory of optimum allocation of resources."

1930, Report on Sets and Projective Sets, First All-U nion $M$ athematical Congress, Kharkov.

1939, "Matematicheskie metody organizatii i planirovania proizvodstva ( $M$ athematical methods in the organization and planning of production), Izdanie Leningradskogo Godsudarstvennogo U niveriteta, Leningrad, translation in: Management Science, 1960, 6, 363-422.

1938, preparation of " $M$ atematicheskie metody organizatii i planirovania proizvodstva, Izdanie Leningradskogo Godsudarstvennogo U niveriteta, L eningrad. 
M other lode publication:

L ast path-breaking publication:

University with motherlode: U niversity with start:

Literature:
1965, Economic Calculation of the Best Use of Resources, $M$ acM illan, N ew Y ork; in Russian: Ekonomicheskii raschot nailushego ispolzovaniya resursov, 1959, Moscow, AN SSSR

1972 (with A.V. Gorstko), Optimal'nye Resheniia V Ekonomike (Optimal Solutions in Economics), Moscow, Nanka.

L eningrad State U niversity

Leningrad State U niversity

L. Johansen, 1976, L.V. Kantorovich's Contribution to Economics, Scandinavian J ournal of Economics, 78, 61-80; M. Ellman, 1973, Problems of Planning in the USSR, Cambridge University Press, Cambridge; R. Gardner, 1990, L.V. Kantorovich: The Price Implications of Optimal Planning, J ournal of E conomic Literature, 28, 638-648.

11.

Name:

Date born:

Died:

Nationality:

Religion:

PhD thesis:

A warded (jointly) in 1975 for:

First publication:

Breakthrough publication:

Start award-winning research

M other lode publication:

L ast path-breaking publication:

University with motherlode:

U niversity with start:

Literature:

12.

Name:

Date born:

Died:
Tjalling C. Koopmans

A ugust 28, 1910

February 26, 1985

Dutch, later U.S.

Christian

1936, U niversity of L eiden

"For their contributions to the theory of optimum allocation of resources."

1933, "Wigners Erweiterung des Thomas-Kuhnschen Summensatzes für ein Elektron in einem Zentralfeld" (with H.A. Kramers and C.C. Jonker), Zeitschrift für Physik, 80, 178-182.

1945, "Statistical Estimation of Simultaneous Economic Relations", J ournal of the American Statistical Association, 40, 448-466.

1942, "Exchange Ratios Between Cargoes on Various Routes", Memorandum for the Combined Shipping A djustment Board, W ashington D.C.

1951, "Activity A nalysis as an Efficient Combination of Activities", in: T.C. Koopmans (ed.), Activity Analysis of Production and Allocation, Wiley, N ew Y ork.

1969, "Maximizing Stationary Utility in a Constant Technology" (with R. Beals), SIAM Journal of Applied Mathematics, 17, 1001-1014.

Chicago University

Combined Shipping A djustment Board, W ashington D.C.

L. Werin, 1976, Tjalling Koopmans' Contributions to Economics, Scandinavian Journal of Economics, 78, 82102.

M ilton Friedman

July 31, 1912 
National ity:

Religion:

PhD thesis:

A warded in 1976 for:

First publication:

Breakthrough publication:

Start award-winning research

M other lode publication:

L ast path-breaking publication:

University with motherlode:

University with start:

Literature:

13.

Name:

Date born:

Died:

Nationality:

Religion:

PhD thesis:

A warded (jointly) in 1977 for:

First publication:

Breakthrough publication:

Start award-winning research

M other lode publication:

L ast path-breaking publication:

University with motherlode:

University with start:

Literature:
U.S.

Jewish

1946, Columbia University

"For his achievements in the fields of consumption analysis, monetary history and theory and for his demonstration of the complexity of stabilization policy."

1935, "Professor Pigou's M ethod of M easuring Elasticities of Demand from Budgetary Data", Quaterly J ournal of Economics, 50, 151-163.

1937, "The Use of Ranks to A void the Assumption of Normality Implicit in the A nalysis of Variance", J ournal of the American Statistical Association, 32, 675-701.

1937, start of project (with S. Kuznets) Incomes from Independent Professional Practice, finished in 1940, published in 1945, NBER, N ew Y ork.

1957, A Theory of the Consumption Function, Princeton University Press, Princeton.

1982, M onetary Trends in the United States and the U nited Kingdom: Their Relations to Income, Prices and Interest Rates, 1867-1975 (with Anna J. Schwartz), Chicago University Press, Chicago.

University of Chicago

NBER

A. Hirsch and N. de Marchi, 1990, Milton Friedman, Economics in Theory and Practice, Harvester Wheatsheaf, New Y ork.

Bertil G. Ohlin

A pril 23, 1899

A ugust 3, 1979

Swedish

Lutheran

1924, U niversity of Stockholm

"For their pathbreaking contribution to the theory of international trade and international capital movements."

1919, "Kvantitesteorin i den svenska litteraturen (The Quantity Theory in the Swedish Literature)", Ekonomisk Tidskrift, reprinted in Economic History, 1950

1929, Transfer Difficulties: Real and Imagined, Economic J ournal

1922, chapters 1-3 and appendix 1 of Interregional and International Trade, then submitted to Economic J ournal.

1933, Interregional and International Trade, Harvard University Press, Cambridge, M ass.

1949, The Problem of Employment Stabilization, Columbia University Press, $\mathrm{N}$ ew $\mathrm{Y}$ ork.

University of Stockholm

University of Stockholm

R.E. Caves, 1978, Bertil Ohlin's Contribution to Economics, Scandinavian J ournal of Economics, 86-99. 
14.

Name:

Date born:

Died:

Nationality:

Religion:

PhD thesis:

A warded (jointly) in 1975 for:

First publication:

Breakthrough publication:

Start award-winning research

M other lode publication:

L ast path-breaking publication:

University with motherlode:

U niversity with start:

Literature:

15.

N ame:

Date born:

Died:

Nationality:

Religion:

PhD thesis:

A warded in 1978 for:

First publication:

Breakthrough publication:

Start award-winning research

M other lode publication:

Last path-breaking publication: U niversity with motherlode: U niversity with start:

Literature:
James E. M eade

June 23, 1907

December 22, 1995

U.K.

Protestant

1930 (BA) Oxford U niversity

"For their pathbreaking contribution to the theory of international trade and international capital movements."

1933, Public Works in their International Aspect, $\mathrm{New}$ Fabian Research Bureau Publication, no. 4, London.

1941, "The Construction of Tables of National Income, Expenditure, Savings and Investment" (with J.E. Meade), E conomic J ournal, 216-231.

1947, preparation of The Theory of International Economic Policy; The Balance of Payments, Oxford University Press, Oxford.

1955, The Theory of International Economic Policy; Trade and Welfare, Oxford U niversity Press, Oxford.

1982, Stagflation, Volume I: Wage Fixing, George Allen \& Unwin, London.

London School of Economics

London School of Economics

H. Johnson, 1978, James Meade's Contribution to Economics, Scandinavian J ournal of Economics, 64-85.

Herbert A. Simon

June 15, 1916

U.S.

Unitarian from a J ewish background

1943, University of Chicago

"For his pioneering research into the decision-making process within economic organizations."

1937, "Comparative Statistics and the Measurement of Efficiency", National Municipal Review, 26, 524-527.

1943, PhD on administrative behaviour.

1947, Administrative Behavior: A Study of Decision Making Processes in Administrative Organizations, M acM illan, N ew Y ork.

1947, Administrative Behavior: A Study of Decision Making Processes in Administrative Organizations, M acM illan, $\mathrm{New}$ Y ork.

1979, A nnual Review of Psychology.

Carnegie-M ellon

U.C. Berkeley

W.J. Baumol, 1979, On the Contributions of Herbert A. Simon to Economics, Scandinavian J ournal of Economics, 74-82; A. A ndo, 1979, On the Contributions of Herbert A. Simon to Economics, Scandinavian J ournal of Economics, 83-114.

16. 
N ame:

D ate born:

Died:

N ationality:

Religion:

PhD thesis:

A warded (jointly) in 1979 for:

First publication:

B reakthrough publication:

Start award-winning research

M other lode publication:

L ast path-breaking publication:

U niversity with motherlode:

U niversity with start:

L iterature:

17.

Name:

$D$ ate born:

Died:

N ationality:

Religion:

PhD thesis:

A warded (jointly) in 1979 for:

First publication:

B reakthrough publication:

Start award-winning research M other lode publication:

L ast path-breaking publication:

University with motherlode:

U niversity with start:

L iterature:
Theodore W. Schultz

A pril 30, 1902

U.S.

Protestant

1930, U niversity of Wisconsin

"For their pioneering research into economic development research with particular consideration of the problems of developing countries."

1932, "Diminishing Returns in View of Progress in A gricultural Production", J ournal of Farm Economics, 14, 640-649.

1945, Agriculture in an Unstable Economy, McGraw-Hill, New Y ork.

1932, "Diminishing Returns in View of Progress in A gricultural Production", J ournal of Farm Economics, 14, 640-649.

1961, "Investment in Human Capital", American Economic Review, 51, 1-17.

1981, Investing in People, The Economics of Population Quality, University of California Press.

University of Chicago

Iowa State College

M.J. Bowman, 1980, On Theodore W. Schultz's Contributions to Economics, Scandinavian Journal of Economics, 80-107; Nobel biography T.W. Schultz.

\section{W. Arthur Lewis, Sir}

January 23, 1915

June 15, 1991

St. L ucian (West Indies), later U.K. and U.S.

Anglican

1937, London School of Economics

"For their pioneering research into economic development research with particular consideration of the problems of developing countries."

1939, Labour in the West Indies, Fabien Society, London.

1949, The Principles of Economic Planning, Allen \& Unwin, London.

1950,

1954, "Economic Development with Unlimited Supplies of Labour, M anchester School, 22, 131-191.

1978, Growth and Fluctuations, 1870-1913, Allen \& Unwin, London.

University of $\mathrm{M}$ anchester

University of $M$ anchester

R. Findlay, 1980, On W. A rthur Lewis' Contributions to Economics, Scandinavian J ournal of Economics, 62-79. 
18.

Name:

Date born:

Died:

Nationality:

Religion:

PhD thesis:

A warded in 1980 for:

First publication:

B reakthrough publication: Start award-winning research

M other lode publication:

L ast path-breaking publication:

University with motherlode:

U niversity with start:

Literature:

19.

N ame:

Date born:

Died:

Nationality:

Religion:

PhD thesis:

A warded in 1981 for:

First publication:

Breakthrough publication:

Start award-winning research

M other lode publication:

L ast path-breaking publication:

University with motherlode:

University with start:

Literature:
Lawrence R. Klein

September 14, 1920

U.S.

Jewish

1944, M.I.T.

"For the creation of econometric models and the application to the analysis of economic fluctuations and economic policies."

1943, "Pitfalls in the Statistical Determination of the Investment Schedule", Econometrica, 11, 246-258.

1947, The Keynesian Revolution, M acM illan, N ew Y ork.

1946, "M acroeconomics and the Theory of Rational Behavior", Econometrica, 14, 93-108.

1950, Economic Fluctuations in the United States, 19211941, Wiley, New Y ork.

1980, Economics of Supply and Demand, Blackwell, Oxford.

University of M ichigan

University of Chicago

R.J. Ball, 1981, On Lawrence Klein's Contributions to Economics, Scandinavian J ournal of Economics, 81-103.

James Tobin

M arch 5, 1918

U.S.

Christian

1947, H arvard University

"For his analysis of financial markets and their relations to expenditure decisions, employment, production and prices." 1941, "A Note on the Money Wage Problem", Quarterly J ournal of Economics, 508-516.

1947, "Liquidity Preference and M onetary Policy", Review of Economics and Statistics, 124-131.

1947, "Liquidity Preference and Monetary Policy", Review of Economics and Statistics, 124-131.

1958, "Liquidity Preference as Behaviour Towards Risk", Review of Economic Studies, 67, 65-86; and "Estimation of Relationships for Limited Dependent Variables", E conometrica, 26, 24-36.

1980, Asset Accumulation and Economic Activity, Blackwell, Oxford.

Y ale U niversity

Harvard U niversity

D.D. Purvis, 1982, James Tobin's Contributions to Economics, Scandinavian J ournal of Economics, 84, 6188;. J. Myhrman, 1982, James Tobin's Contributions to Economics, Scandinavian Journal of Economics, 84, 89110. 
20.

N ame:

D ate born:

Died:

N ationality:

Religion:

PhD thesis:

A warded in 1982 for:

First publication:

Breakthrough publication:

Start award-winning research

M other lode publication:

L ast path-breaking publication:

U niversity with motherlode:

U niversity with start:

L iterature:

21.

N ame:

D ate born:

Died:

$\mathrm{N}$ ationality:

Religion:

PhD thesis:

$M$ ajor influence

A warded in 1983 for:

First publication:

Breakthrough publication:

Start award-winning research

M other lode publication:

L ast path-breaking publication:

U niversity with motherlode:

U niversity with start:

L iterature:
George J. Stigler

January 17, 1911

December 1, 1991

U.S.

Christian

1938, U niversity of Chicago

"For his seminal studies of industrial structures, functioning of markets and causes and effects of public regulation."

1937, "The Economics of Carl Menger", Journal of Political Economy, 45, 229-250.

1939, "Production and Distribution in the Short Run", J ournal of Political Economy, 47, 305-327.

1946, Roofs or Ceilings? (together with M ilton Friedman), Foundation for Economic Research, Irvington-on -Hudson.

1961, "The Economics of Information", J ournal of Political Economy, 69, 213-225.

1977, "De Gustibus Non Est Disputandum" (with G.S. Becker), American Economic Review, 67, 76-90.

University of Chicago

University of M innesota

G.J. Stigler, 1988, Memoirs of an U nregulated Economist, Basic Books, New York; V.M. Longawa, 1993, George J. Stigler: A Bibliography, J ournal of Political Economy, 101, 849-862.

Gerard Debreu

July 4, 1921

French, later U.S.

Christian

1946, E cole Normale Superieure; 1956, U niversite de Paris $M$ aurice $A$ llais

"For having incorporated new analytical methods into economic theory and for his rigorous reformulation of the theory of general equilibrium."

1951, "The Coefficient of Resource Utilization", Econometrica, 19, 273-292.

1954, "Existence of an Equilibrium for a Competitive Economy" (with K.J. A rrow), Econometrica, 22, 265-290.

1951, "The Coefficient of Resource Utilization", Econometrica, 19, 273-292.

1959, Theory of Value - An Axiomatic Analysis of Market Equilibrium, Wiley, New Y ork.

1974, "Excess Demand Functions", Journal of Mathematical Economics, 1, 15-21.

$Y$ ale University

Chicago University

H. Varian, 1984, Gerard Debreu's Contributions to Economics, Scandinavian J ournal of Economics, 86, 4-14. 
22.

Name:

D ate born:

Died:

N ationality:

Religion:

PhD thesis:

A warded in 1984 for:

First publication:

B reakthrough publication:

Start award-winning research

M other lode publication:

L ast path-breaking publication:

U niversity with motherlode:

U niversity with start:

L iterature:

23.

N ame:

D ate born:

Died:

N ationality:

Religion:

PhD thesis:

A warded in 1985 for:

First publication:

Breakthrough publication:

Start award-winning research

M other lode publication:

L ast path-breaking publication:

U niversity with motherlode:

U niversity with start:

L iterature:
J ohn Richard N. Stone, Sir

A ugust 30, 1913

1991

U.K.

Protestant

1957, Cambridge U niversity

"For having made fundamental contributions to the development of systems of national accounts and hence greatly improved the basis for empirical economic analysis."

1936, "A Study of Costs" (with W.A. Twaddle), E conometrica, 4, 226-241.

1941, "The Construction of Tables of National Income, Expenditure, Savings and Investment" (with J.E. M eade), Economic J ournal, 216-231.

1940, survey of U.K. economy (with J.E. M eade), published in: An Analysis of the Sources of War Finance and an Estimate of the National Income and Expenditure in 1938 and 1940, White Paper, War Cabinet.

1946, National Income and Expenditure (with J.E. M eade), Oxford University Press, Oxford.

1969, Demographic Accounting and Model Building, OECD, Paris.

Cambridge University

British Government Offices, L ondon.

M.H. Pasaran, 1991, The ET Interview: Professor Sir Richard Stone, Econometric Theory, 7, 85-123.

Franco M odigliani

June 18, 1918

Italian, later U.S.

Jewish

1944, N ew School for Social Research, N ew Y ork

"For his pioneering analyses of saving and of financial markets."

1944, "Liquidity Preference and the Theory of Interest and M oney", Econometrica, 12, 45-88.

1944, "Liquidity Preference and the Theory of Interest and M oney", Econometrica, 12, 45-88.

1944, "Liquidity Preference and the Theory of Interest and M oney", Econometrica, 12, 45-88.

1954, "Utility and the Consumption Function: An Interpretation of Cross-Section Data" (with R. Brumberg), in: K.K. Kurihara (ed.), Post-K eynesian E conomics, Rutgers University Press, New Brunswick.

1982, "Debt, Dividend Policy, Taxes, Inflation and M arket Valuation", J ournal of Finance, 37, 255-273.

Carnegie-M ellon

New School for Social Research, N ew Y ork

R.C. Merton, 1987, In Honor of Nobel Laureate, Franco M odigliani, J ournal of Economic Perspectives, 1, 145-155. 
24.

N ame:

Date born:

Died:

N ationality:

Religion:

PhD thesis:

A warded in 1986 for:

First publication:

B reakthrough publication:

Start award-winning research

M other lode publication:

L ast path-breaking publication:

U niversity with motherlode:

U niversity with start:

L iterature:
James M. Buchanan, J r.

October 2, 1919

U.S.

Christian

1948, U niversity of Chicago

"For his development of the contractual and constitutional bases for the theory of economic and political

decision-making."

1949, "Regional Implications of Marginal Cost Rate M aking", Southern Economic J ournal, 16, 53-61.

1950, "Federalism and Fiscal Equity", American Economic Review, 40, 583-599.

1949, "The Pure Theory of Government Finance: A Suggested Approach", Journal of Political Economy,57, 496-505.

1962, The Calculus of Consent (with G. Tullock), University of Michigan Press, Ann A rbor.

1980, "Rent Seeking and Profit Seeking", in: J.M. Buchanan, R. Tollison, and G. Tullock (eds.), Toward a Theory of the Rent Seeking Society, Texas A\&M University Press.

University of $\mathrm{V}$ irginia

University of Tennessee

T. Romer, 1988, Nobel Laureate: On James Buchanan's Contributions to Public Economics, Journal of Economic Perspectives, 2, 165-179; J.M. Buchanan, 1992, Better than Plowing and Other Personal Essays, Chicago University Press, Chicago.

25.

N ame:

D ate born:

Died:

N ationality:

Religion:

PhD thesis:

A warded in 1987 for:

First publication:

Breakthrough publication:

Start award-winning research

M other lode publication:

L ast path-breaking publication:

U niversity with motherlode:

U niversity with start:

L iterature:
Robert M. Solow

A ugust 23, 1924

U.S.

Jewish

1951, H arvard University

"For his contributions to the theory of economic growth." 1951, "Some Long Run A spects of the Distribution of W age Incomes", Econometrica,

1956, "A Contribution to the Theory of Economic Growth", Q uarterly J ournal of Economics, 70, 65-94.

1955, "The Production Function and the Theory of Capital", Review of Economic Studies, 23, no. 2

1956, "A Contribution to the Theory of Economic Growth", Quarterly J ournal of Economics, 70, 65-94.

1980, "On Theories of Unemployment", American Economic Review, 1-11.

M.I.T.

M.I.T.

A.S. Blinder, 1989, In Honor of Robert M. Solow: Nobel L aureate in 1987, J ournal of Economic Perspectives, 3, 99105. 
26.

N ame:

D ate born:

Died:

N ationality:

Religion:

PhD thesis:

A warded in 1988 for:

First publication:

Breakthrough publication:

Start award-winning research

M other lode publication:

Last path-breaking publication:

University with motherlode:

University with start:

Literature:

27.

Name:

Date born:

Died:

Nationality:

Religion:

PhD thesis:

Awarded in 1989 for:

First publication:

Breakthrough publication:

Start award-winning research

Mother lode publication:

Last path-breaking publication:

University with motherlode:

University with start

Literature:
M aurice F.C. Allais

M ay 31, 1911

French

Christian

1936, Ecole Polytechnique (bacc.); 1949, Ecole Nationale Superieure des M ines de Paris.

"For his pioneering contributions to the theory of markets and efficient utilization of resources."

1943, A Recherche d'une Discipline Economique, Premiere partie: L'Economie pure, A teliers Industria, Paris.

1943, A Recherche d'une Discipline Economique, Premiere partie: L'Economie pure, A teliers Industria, Paris.

1943, A Recherche d'une Discipline Economique, Premiere partie: L'Economie pure, A teliers Industria, Paris.

1947, Economie et Intérêt, Imprimerie National, Paris.

1979, "The So-called Allais paradox and Rational Decisions

Under Uncertainty", in: M. Allais and O. Hagen (eds.), Expected Utility Hypotheses and the Allais Paradox, Reidel, Dordrecht.

Ecole Nationale Superieure des Mines de Paris.

Ecole Nationale Superieure des Mines de Paris.

B.R. Munier, 1991, Nobel Laureate, The Many Other Allais Paradoxes, Journal of Economic Perspectives, 5, 179-199.

Trygve Haavelmo

December 13, 1911

Norwegian

Christian

1941, Harvard University

"For his clarification of the probability theory foundations of econometrics and his analyses of simultaneous economic structures."

1938, "The Method of Supplementary Confluent Relations, Illustrated by a Study of Stock Prices", Econometrica, 6, 203-218.

1943, "The Statistical Implications of a System of Simultaneous Equations", Econometrica, 11, 1-12.

1941, The Probability Approach in Econometrics, PhD thesis, $\mathrm{H}$ arvard.

1944, "The Probability Approach in Econometrics", Econometrica, Supplement, 12.

1960, A Study in the Theory of Investment, Chicago University Press, Chicago.

Harvard University

Harvard University

K.O. Moene, and A. Rodseth, 1991, Nobel Laureate, Trygve Haavelmo, Journal of Economic Perspectives, 5, 175-192. 
28.

Name:

Date born:

Died:

Nationality:

'Religion:

PhD thesis:

A warded (jointly) in 1990 for:

First publication:

Breakthrough publication:

Start award-winning research

Mother lode publication:

Last path-breaking publication:

University with motherlode: University with start:

Literature:

29.

Name:

Date born:

Died:

Nationality:

Religion:

PhD thesis:

Awarded (jointly) in 1990 for:

First publication:

Breakthrough publication:

Start award-winning research

Mother lode publication:

Last path-breaking publication:

University with motherlode:

University with start:

Literature:
Merton H. Miller

May 16, 1923

U.S.

Jewish

1952, Johns Hopkins University

"For their pioneering work in the theory of financial economics."

1948, "Built in Flexibility" (with R.A. Musgrave), American Economic Review,

1958, "The Cost of Capital, Corporation Finance and the Theory of Investment" (with F. Modigliani), American Economic Review, 48, 261-297.

1956, preparation of The Cost of Capital..

1958, "The Cost of Capital, Corporation Finance and the Theory of Investment" (with F. Modigliani), American Economic Review, 48, 261-297.

1982, (with Myron Scholes) "Dividends and Taxes: Some Empirical Evidence", Journal of Political Economy, 90, 1118-1141.

Carnegie-Mellon

Carnegie-Mellon

H. Varian, 1993, A Portfolio of Nobel Laureates: Markowitz, Miller and Sharpe, Journal of Economic Perspectives, 7, 159-169; P. Bernstein, 1992, Capital Ideas, Free Press, New York.

Harry M. Markowitz

August 24, 1927

U.S.

Jewish

1954, University of Chicago

"For their pioneering work in the theory of financial economics."

1952, "Portfolio Selection", Journal of Finance, 1952, 7, 77-91.

1952, "Portfolio Selection", Journal of Finance, 1952, 7, $77-91$.

1951.

1959, Portfolio Selection: Efficient Diversification of Investments, Wiley, New York.

1987, Mean Variance Analysis in Portfolio Choic and Capital Markets, Blackwell, Oxford.

RAND Corporation

University of Chicago

H. Varian, 1993, A Portfolio of Nobel Laureates: Markowitz, Miller and Sharpe, Journal of Economic Perspectives, 7, 159-169. 
30.

Name:

Date born:

Died:

Nationality:

Religion:

$\mathrm{PhD}$ thesis:

A warded (jointly) in 1990 for:

First publication:

Breakthrough publication:

Start award-winning research

Mother lode publication:

Last path-breaking publication: University with motherlode:

University with start:

Literature:

31.

Name:

Date born:

Died:

Nationality:

Religion:

PhD thesis:

Awarded in 1991 for:

First publication:

Breakthrough publication: Start award-winning research

Mother lode publication:

Last path-breaking publication:

University with motherlode:

University with start:

Literature:
William F. Sharpe

June 16, 1934

U.S.

n.a.

1961, University of California, L.A.

"For their pioneering work in the theory of financial economics."

1961, "Aircraft Compartment Design Criteria for the Army Development Mission", Naval Research Logistics Quarterly, 8, 381-394.

1963, "A Simplified Model for Portfolio Analysis", Management Science, 9, 277-293.

1961, derivation of "A Simplified Model for Portfolio A nalysis".

1964, "Capital Asset Prices: A Theory of Market Equilibrium Under Conditions of Risk", Journal of Finance, 19, 425-442.

1978, Investments, Prentice Hall, London.

University of Washington

RAND

H. Varian, 1993, A Portfolio of Nobel Laureates: Markowitz, Miller and Sharpe, Journal of Economic Perspectives, 7, 159-169.

Ronald H. Coase

December 29, 1910

U.K., later U.S. (1951)

n.a.

1951, London School of Economics

"For his discovery and clarification of the significance of transaction costs and property rights for the institutional structure and functioning of the economy."

1935, "The Problem of Duopoly Reconsidered", Review of Economic Studies, 2, 137.

1937, "The Nature of the Firm", Economica, 386-405.

1932, "The Nature of the Firm", lecture in Dundee, October of that year.

1937, "The Nature of the Firm", Economica, 386-405.

1974, "The Lighthouse in Economics", Journal of Law and Economics, 17,

London School of Economics

London School of Economics

R.A. Posner, 1993, Nobel Laureate, Ronald Coase and Methodology, Journal of Economic Perspectives, 7, 195210. 
32.

Name:

Date born:

Died:

Nationality:

Religion:

PhD thesis:

$M$ ajor influence:

Awarded in 1992 for:

First publication:

Breakthrough publication:

Start award-winning research

Mother lode publication:

Last breaking publication:

University with motherlode:

University with start:

Literature:

33.

Name:

Date born:

Died:

Nationality:

Religion:

PhD thesis:

A warded (jointly) in 1993 for:

First publication:

Breakthrough publication:

\section{Start award-winning research}

Mother lode publication:

Last path-breaking publication:

University with motherlode:

University with start:

Literature:
Gary S. Becker

December 2, 1930

U.S.

Jewish

1955, University of Chicago

M. Friedman, T.W. Schultz

"For having extended the domain of microeconomic analysis to a wide range of human behaviour and interaction, including nonmarket behaviour."

1952, "A Note on Multi-Country Trade", American Economic Review, 42, 558-568.

1957, The Economics of Discrimination, University of Chicago Press, Chicago.

1955, The Economics of Discrimination, PhD Thesis, University of Chicago.

1964, Human Capital, Columbia University Press, New York.

1988, "A Theory of Rational Addiction" (with K.M. Murphy), Journal of Political Economy, 96, 675-700.

University of Chicago

University of Chicago

V.R. Fuchs, 1994, Nobel Laureate Gary S. Becker: Ideas about Facts, Journal of Economic Perspectives, 8, 183-192; and A. Sandmo, 1993, Gary Becker's Contribution to Economics, Scandinavian Journal of Economics, 95, 7-23.

Robert W. Fogel

July 1, 1926

U.S.

Jewish

1963, Johns Hopkins University

"For having renewed research in economic history by applying economic theory and quantitative methods in order to explain economic and institutional change."

1960, The Union Pacific Railroad: A Case in Premature Enterprise, John Hopkins University Press.

1964, Railroads and American Economic Growth, Essays in Econometric History, Johns Hopkins University Press, Baltimore.

1963, Railroads and American Economic Growth, Essays in E conometric History, PhD, J ohns Hopkins U niversity.

1974, Time on the Cross: The Economics of American Negro Slavery (with Stanley L. Engerman), Little, Boston. 1992, "Second Thoughts on the European Escape from Hunger: Famines, Chronic Malnutrition and Mortality, in: S.R. Osmani (ed.), Nutrition and Poverty, Clarendon Press, Oxford.

University of Chicago

Johns Hopkins University

C. Goldin, 1995, Cliometrics and the Nobel, Journal of Economic Perspectives, 9, 191-208. 
34.

Name:

Date born:

Died:

Nationality:

Religion:

PhD thesis:

Awarded (jointly) in 1993 for:

First publication:

Breakthrough publication:

Start award-winning research

Mother lode publication:

Last path-breaking publication:

University with motherlode:

University with start:

Literature:

35.

Name:

Date born:

Died:

Nationality:

Religion:

PhD thesis:

A warded (jointly) in 1994 for:

First publication:

Breakthrough publication:

Start award-winning research

Mother lode publication:

Last path-breaking publication:

University with motherlode:

University with start:

Literature:
Douglass C. North

November 5, 1920

U.S.

n.a.

1952, University of California, Berkeley

"For having renewed research in economic history by applying economic theory and quantitative methods in order to explain economic and institutional change."

1950, "Some Recent Views of the Modern Large Corporation", Explorations in Entrepreneurial History, 2, 71-90.

1955, "Location Theory and Regional Economic Growth", J ournal of Political Economy,

1955, "Location Theory and Regional Economic Growth", J ournal of Political Economy,

1961, The Economic Growth of the United States, 17901860, Prentice Hall, New York.

1990, Institutions, Institutional Change and Economic Performance, Cambridge University Press, Cambridge.

University of Washington

University of California, Berkeley

C. Goldin, 1995, Cliometrics and the Nobel, Journal of Economic Perspectives, 9, 191-208.

John F. Nash Jr.

June 13, 1928

U.S.

n.a.

1950 (Mathematics), Princeton University

"For their pioneering analysis of equilibria in the theory of non-cooperative games."

1950, "Equilibrium Points in n-Person Games", Proceedings of the National Academy of Sciences, 36, 4849.

1950, "The Bargaining Problem", Econometrica, 18, 155162.

1949, start PhD.

1950, "The Bargaining Problem", Econometrica, 18, 155162.

1953, "Two-Person Cooperative Games", Econometrica, 21, 286-295.

Princeton University

Princeton University

A. Rubinstein, 1995, John Nash: The Master of Economic Modeling, Scandinavian Journal of Economics, 97, 15-40; E.E.C. van Damme and J.W. Weibull, 1995, Equilibrium in Strategic Interaction: The Contributions of John C. Harsanyi, John F. Nash and Reinhard Selten, Scandinavian Journal of Economics, 97, 15-40. 
36.

Name:

Date born:

Died:

Nationality:

Religion:

PhD thesis:

A warded (jointly) in 1994 for:

First publication:

Breakthrough publication:

Start award-winning research

Mother lode publication:

Last path-breaking publication:

University with motherlode:

University with start:

Literature:

37.

Name:

Date born:

Died:

Nationality:

Religion:

PhD thesis:

Awarded (jointly) in 1994 for:

First publication:

Breakthrough publication:

Start award-winning research

Mother lode publication:
Reinhard Selten

October 5, 1930

German

Jewish background

1961 (Mathematics), University of Frankfurt, 1968 (Economics)

"For their pioneering analysis of equilibria in the theory of non-cooperative games."

1959, "Ein Oligopolexperiment" (with H. Sauermann), Zeitschrift für die gesamte Staatswissenschaft, 115, 427471.

1965, "Spieltheoretische Behandlung eines Oligopolmodells mit Nachfrageträgheit", Zeitschrift für die gesamte Staatswissenschaft, 121, 301-324 and 667-689.

1957, starting work on experimental games.

1975, "Reexamination of the Perfectness Concept for Equilibrium Points in Extensive Games", International J ournal of Game Theory, 4, 25-55.

1988, A General Theory of Equilibrium Selection in Games (with J.R. Harsanyi), MIT Press, Cambridge, Mass.

University of Bielefeld

University of Frankfurt

E.E.C. van Damme and J.W. Weibull, 1995, Equilibrium in Strategic Interaction: The Contributions of John C. Harsanyi, John F. Nash and Reinhard Selten, Scandinavian Journal of Economics, 97, 15-40.

John C. Harsanyi

May 29, 1920

Hungarian, later U.S.

Jewish background

1947 (philosophy), University of Budapest; 1959 (economics), Stanford University

"For their pioneering analysis of equilibria in the theory of non-cooperative games."

1953, "Cardinal Utility in Welfare Economics and in the Theory of Risk-taking, Journal of Political Economy, 61, 434-435.

1955, "Cardinal Welfare, Individualistic Ethics, and Interpersonal Comparisons of Utility", Journal of Political Economy, 63, 309-321.

1956, "Approaches to the Bargaining Problem Before and After the Theory of Games: A Critical Discussion of Zeuthen's, Hicks' and Nash's Theories", Econometrica, 24, 144-157.

1967-68, "Games with Incomplete Information Played by 'Bayesian' Players, Part I: The Basic Model (November 1967); Part II: Bayesian Equilibrium Points (January 1968); and Part III: The Basic Probability Distribution of the Game (March 1968), Management Science, 14, 159-182; 320-334; and 486-502. 
Last path-breaking publication:

University with motherlode:

University with start:

Literature:

38.

Name:

Date born:

Died:

Nationality:

Religion:

PhD thesis:

Awarded in 1995 for:

First publication:

Breakthrough publication:

Start award-winning research

Mother lode publication:

Last path-breaking publication: University with motherlode: University with start:

Literature:

39.

Name:

Date born:

Died:

Nationality:

Religion:

PhD thesis:

A warded (jointly) in 1996 for

First publication:

Breakthrough publication:
1988, A General Theory of Equilibrium Selection in Games (with R. Selten), MIT Press, Cambridge, Mass.

Stanford University

Stanford University

E.E.C. van Damme and J.W. Weibull, 1995, Equilibrium in Strategic Interaction: The Contributions of John C. Harsanyi, John F. Nash and Reinhard Selten, Scandinavian Journal of Economics, 97, 15-40.

Robert J. Lucas, Jr.

September 15, 1937

U.S.

n.a.

1964, University of Chicago

"For having developed and applied the hypothesis of rational expectations, and thereby having transformed macroeconomic analysis and deepened our understanding of economic policy."

1962, "Notes on Estimated Aggregate Quarterly Consumption Functions" (with Z. Griliches, G.S. Maddala, and N. Wallace), Econometrica, 1962.

1967, "Adjustment Costs and the Theory of Supply", Journal of Political Economy, 321-334.

1970, derivation of "Expectations and the Neutrality of M oney", J ournal of E conomic Theory, 4, 103-124.

1972, "Expectations and the Neutrality of Money", Journal of Economic Theory, 4, 103-124.

1993, "Making a Miracle", Econometrica, 61, 251-272.

Carnegie-Mellon

Carnegie-Mellon

L.E.O. Svensson, 1996, The Scientific Contributions of Robert E. Lucas, Jr., Scandinavian Journal of Economics, 98, 1-10; S. Fischer, 1996, Robert Lucas's Nobel Memorial Prize, Scandinavian Journal of Economics, 98, 11-31; and R.E. Hall, 1996, Robert Lucas, Recipient of the 1995 Nobel Memorial Prize in Economics, Scandinavian Journal of Economics, 98, 33-48.

James A. Mirrlees

1936

U.K.

n.a.

1963, University of Cambridge

"For their fundamental contributions to the economic theory of incentives under asymmetric information."

1962, "A New Model of Economic Growth" (with N. Kaldor), Review of Economic Studies, 29, 174-192.

1971, "An Exploration in the Theory of Optimum Income Taxation", Review of Economic Studies, 38, 175-208. 
Start award-winning research

Mother lode publication:

Last path-breaking publication:

University with motherlode:

University with start:

Literature:

40.

Name:

Date born:

Died:

Nationality:

Religion:

PhD thesis:

Awarded (jointly) in 1996 for

First publication:

Breakthrough publication:

Start award-winning research

Mother lode publication:

Last path-breaking publication:

University with motherlode:

University with start:

Literature:

41.

Name:

Date born:

Died:

Nationality:

Religion:

PhD thesis:

Awarded (jointly) in 1997 for

First publication:
1971, "An Exploration in the Theory of Optimum Income Taxation", Review of Economic Studies, 38, 175-208. (derived in 1968)

1971, "An Exploration in the Theory of Optimum Income Taxation", Review of Economic Studies, 38, 175-208.

1986, The Theory of Optimal Taxation, in: K.J. Arrow and M.D. Intriligator (eds.), Handbook of Mathematical Economics, vol. III, North-Holland, Amsterdam.

University of Oxford

University of Oxford

A. Dixit, and T. Besley, 1997, James Mirrlees' Contributions to the Theory of Information and Incentives, Scandinavian Journal of Economics, 99, 207-235.

William S. Vickrey

June 21,1914

October 10, 1996

Canadian

n.a.

1947, Columbia University

"For their fundamental contributions to the economic theory of incentives under asymmetric information."

1938, "A Comparison of Aggregate Burdens of Federal Income Tax and State Income Tax in 11 Selected States" (with C. Shoup and B.L. Shimberg), in: Studies in Current Tax Problems, Twentieth Century Fund, pp. 523-961.

1945, "Measuring Marginal Utility by Reactions to Risk", Econometrica, 13, 319-333.

1945, "Measuring M arginal Utility by Reactions to Risk", Econometrica, 13, 319-333.

1961, "Counterspeculation, Auctions, and Competitive Sealed Tenders", Journal of Finance, 16, 8-37.

1969, "Congestion Theory and Transport Investment", American Economic Review, 59, 251-260.

Columbia University

Columbia University

J. Dreze, 1997, Research and Development in Public Economics: William Vickrey's Inventive Quest of Efficiency, Scandinavian Journal of Economics, 99, 179198.

Robert C. Merton

1944

U.S.

n.a.

1970, MIT

"a new method to determine the value of derivatives."

1966, The 'Motionless' Motion of Swift's Flying Island, Journal of the History of Ideas. 
Breakthrough publication:

Start award-winning research

Mother lode publication:

Last path-breaking publication:

University with motherlode:

University with start:

Literature:

42.

Name:

Date born:

Died:

Nationality:

Religion:

PhD thesis:

A warded (jointly) in 1997 for

First publication:

Breakthrough publication:

Start award-winning research

M other lode publication:

L ast path-breaking publication:

U niversity with motherlode:

U niversity with start:

L iterature:
1969, Lifetime Portfolio Selection under Uncertainty: The Continuous-Time Case, Review of Economics and Statistics, 51, 247-257.

1970, A Dynamic General Equilibrium Model of the Asset Market and Its Application to the Pricing of the Capital Structure of the Firm, Working paper, no. 497-70, Sloan Management School MIT, reprinted in: R.C. Merton, Continuous-Time Finance, Blackwell, New York, pp. 357387.

1973, The Theory of Rational Option Pricing, Bell Journal of Economics and Management Science, 4, 637-654.

1987, A Simple Model of Capital Market Equilibrium with Incomplete Information, Journal of Finance, 42, 483-510.

MIT

MIT

Myron S. Scholes

1941

-

U.S.

n.a.

1969, University of Chicago

"a new method to determine the value of derivatives."

1972 (with F. Black), The Valuation of Option Contracts and a Test of Market Efficiency, Journal of Finance, 27, 399-417.

1972 (with F. Black), The Valuation of Option Contracts and a Test of Market Efficiency, Journal of Finance, 27, 399-417.

1968, development of the Black-Scholes formula for options in 1970 submitted to JPE, but first rejected.

1973 (with F. Black), The Pricing of Options and Corporate Liabilities, J ournal of Political Economy, 81, 637-654.

1992 (with M.A. Wolfson), Taxes and Business Strategy: A Planning Approach, Prentice Hall, Englewood Cliffs, NJ.

MIT

MIT

"Stanford's Scholes wins Nobel for Economics", Stanford University News Service, October 14, 1997. 